\title{
Melt inclusion constraints on petrogenesis of the 2014-2015 Holuhraun eruption, Iceland
}

\author{
Margaret E. Hartley ${ }^{1}$ (1) $\cdot$ Enikö Bali $^{2} \cdot$ John Maclennan $^{3} \cdot$ David A. Neave $^{4} \cdot$ Sæmundur A. Halldórsson $^{2}$
}

Received: 7 January 2017 / Accepted: 20 December 2017 / Published online: 12 January 2018

(c) The Author(s) 2018. This article is an open access publication

\begin{abstract}
The 2014-2015 Holuhraun eruption, on the Bárðarbunga volcanic system in central Iceland, was one of the best-monitored basaltic fissure eruptions that has ever occurred, and presents a unique opportunity to link petrological and geochemical data with geophysical observations during a major rifting episode. We present major and trace element analyses of melt inclusions and matrix glasses from a suite of ten samples collected over the course of the Holuhraun eruption. The diversity of trace element ratios such as $\mathrm{La} / \mathrm{Yb}$ in Holuhraun melt inclusions reveals that the magma evolved via concurrent mixing and crystallization of diverse primary melts in the mid-crust. Using olivine-plagioclase-augite-melt (OPAM) barometry, we calculate that the Holuhraun carrier melt equilibrated at $2.1 \pm 0.7 \mathrm{kbar}(7.5 \pm 2.5 \mathrm{~km})$, which is in agreement with the depths of earthquakes $(6 \pm 1 \mathrm{~km})$ between Bárðarbunga central volcano and the eruption site in the days preceding eruption onset. Using the same approach, melt inclusions equilibrated at pressures between 0.5 and $8.0 \mathrm{kbar}$, with the most probable pressure being 3.2 kbar. Diffusion chronometry reveals minimum residence timescales of 1-12 days for melt inclusionbearing macrocrysts in the Holuhraun carrier melt. By combining timescales of diffusive dehydration of melt inclusions with the calculated pressure of $\mathrm{H}_{2} \mathrm{O}$ saturation for the Holuhraun magma, we calculate indicative magma ascent rates of $0.12-0.29 \mathrm{~m} \mathrm{~s}^{-1}$. Our petrological and geochemical data are consistent with lateral magma transport from Bárðarbunga volcano to the eruption site in a shallow- to mid-crustal dyke, as has been suggested on the basis of seismic and geodetic datasets. This result is a significant step forward in reconciling petrological and geophysical interpretations of magma transport during volcano-tectonic episodes, and provides a critical framework for the interpretation of premonitory seismic and geodetic data in volcanically active regions.
\end{abstract}

Keywords Iceland $\cdot$ Holuhraun $\cdot$ Melt inclusions $\cdot$ Crystallization $\cdot$ Melt barometry

\section{Introduction}

Communicated by Othmar Müntener.

Electronic supplementary material The online version of this article (https://doi.org/10.1007/s00410-017-1435-0) contains supplementary material, which is available to authorized users.

Margaret E. Hartley

margaret.hartley@manchester.ac.uk

1 School of Earth and Environmental Sciences, University of Manchester, Manchester, UK

2 Institute of Earth Sciences, University of Iceland, Reykjavík, Iceland

3 Department of Earth Sciences, University of Cambridge, Cambridge, UK

4 Institut für Mineralogie, Leibniz Universität Hannover, Hannover, Germany
The recent eruption at Holuhraun within the Bárðarbunga volcanic system in central Iceland began on 29 August 2014 and, with the exception of a short break in activity on 30 August, continued until 27 February 2015, producing over $1.4 \mathrm{~km}^{3}$ of dominantly plagioclase-phyric lava and tephra. The event was one of the best-monitored basaltic fissure eruptions that have ever occurred, and presents a unique opportunity to link petrological and geochemical data with geophysical observations during a major rifting episode. It also provides an excellent opportunity to investigate mechanisms of melt generation and its subsequent storage and transport within Iceland's axial rift zones.

We present a detailed petrological and geochemical characterization of erupted products from Holuhraun. We use these data to evaluate pressures of melt mixing, storage, 
and equilibration in the Holuhraun magmatic system. We present a new implementation of the olivine-plagioclase-augite-melt (OPAM) barometer (Yang et al. 1996) to evaluate melt equilibration pressures, whereby melt compositions that are not multiply saturated can be identified and discarded, and the systematic error in returned pressure estimates is minimised. We use diffusion chronometry to estimate minimum residence times of macrocryst phases in the Holuhraun melt, and obtain indicative ascent rates for the Holuhraun magma. Finally, we compare our petrological observations with geophysical data to evaluate the fidelity of petrological and geochemical datasets in recovering the apparent magma storage and transport during a major volcano-tectonic episode. In studies of previous, similar volcano-tectonic events in Iceland, petrologists have typically evaluated the depths of magma storage and transport as being significantly deeper than the recorded seismicity. Here, for the first time, we have recovered petrological constraints on melt storage and transport pressures that are in very good agreement with seismic and geodetic determinations from the same event. This marks a significant step forward towards the reconciliation of petrological and geophysical datasets. Our methods and results are applicable to the interpretation of melt transport pathways during historical eruptions where geophysical and geodetic data are not available, and may lead to significant improvements in the forecasting of future fissure eruptions, both in Iceland and further afield.

\section{Geological background}

\section{Melt transport in Icelandic systems}

Volcano-tectonic episodes in Iceland include the 1975-1984 Krafla Fires (Björnsson et al. 1977; Einarsson and Brandsdóttir 1979), Askja 1874-1876 (Macdonald et al. 1987; Hartley and Thordarson 2013), Laki 1783-1784 and Eldgja 934 (Sigurdsson and Sparks 1978; Thordarson and Self 1993). With the exception of the Krafla Fires, no highresolution seismic or geodetic data exist for these volcanotectonic episodes. Thus, evaluation of magma supply and transport for Icelandic historic volcano-tectonic episodes has, to date, relied on the interpretation of petrological and geochemical data, supported by low-resolution records of seismicity and/or ground deformation gleaned from historical accounts when available (e.g., Hartley and Thordarson 2012). This has resulted in two principal end-member hypotheses describing the possible nature of magmatic plumbing systems feeding fissure eruptions in volcanic rift zones. First, replenishment and pressurization of a magma chamber beneath the volcanic edifice may result in lateral magma injection into the mid to upper crust in the direction of maximum tensile stress, resulting in laterally propagating seismicity and potentially a fissure eruption along the rift zone (e.g., Sigurdsson and Sparks 1978). Magma withdrawal from a shallow magma chamber may also result in caldera subsidence at the volcanic edifice (e.g., Stix and Kobayashi 2008, and references therein). Alternatively, fissure eruptions along rift zones may be driven by pressurization of lower crustal magma reservoirs and the injection of subvertical dykes towards the surface, with associated movement on caldera ring faults resulting from the concentration of dyke-induced stress fields around pre-existing faults and/or shallow magma chambers (e.g., Gudmundsson 1995; Gudmundsson et al. 2014). These models have been discussed extensively with respect to volcano-tectonic episodes for volcanic edifices including Kilauea, Hawaii (Ryan 1988; Baker and Amelung 2012); the Afar region of Ethiopia (Wright et al. 2006; Jeir et al. 2009; Ebinger et al. 2010); and mid-ocean ridge segments (e.g., Fialko and Rubin 1998; Dziak et al. 1995; Escartín et al. 2014).

The 2014-2015 event at Holuhraun is the best-monitored Icelandic volcano-tectonic episode ever to have occurred. For the first time, we have interlinked high-resolution datasets describing the seismicity (Sigmundsson et al. 2015; Ágústsdóttir et al. 2016) and ground deformation (Gudmundsson et al. 2016), as well as changes in volcanic plume chemistry (Gauthier et al. 2016), all of which can be directly linked to the petrology and geochemistry of erupted products collected at regular intervals over the course of the eruption (Fig. 1). The Holuhraun eruption thus represents a unique opportunity to integrate the petrological characteristics of the erupted products from a volcano-tectonic episode with various geophysical datasets, and hence to evaluate the most likely model of melt transport in the light of multiple independent, high-quality datasets. This not only enhances our ability to interpret magma storage and transport pathways during historic volcano-tectonic episodes, where such geophysical data are unavailable, but also provides a vital framework for the interpretation of premonitory seismic and geodetic data in volcanically active regions, which is crucial to improving volcano monitoring and the response to future eruptive hazards.

\section{Geophysical observations of the Holuhraun volcano-tectonic episode}

Intense seismicity on the Bárðarbunga volcanic system commenced on 16 August 2014, with the distribution of seismicity consistent with a radial dyke propagating northeastwards from Bárðarbunga volcano. Simultaneously, GPS observations recorded subsidence at Bárðarbunga caldera, and extension perpendicular to the propagating dyke (Sigmundsson et al. 2015). Dyke propagation continued at a variable rate until 29 August 2015, with earthquake hypocentral 

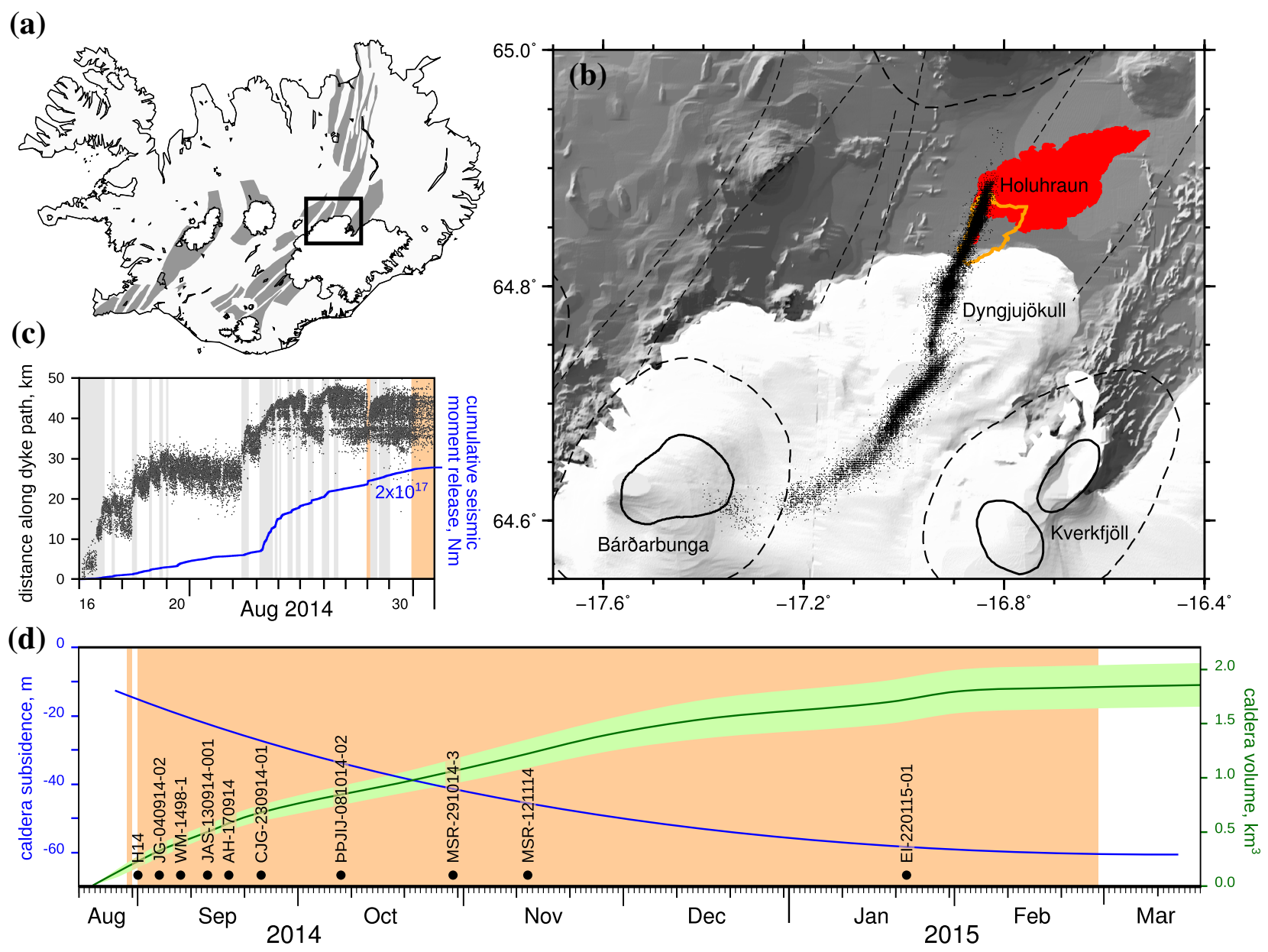

Fig. 1 a Map of Iceland showing the neovolcanic rift zones. b Map of central Iceland showing central volcanoes and their fissure swarms. The 2014-2015 Holuhraun lava is shaded in red; the orange line shows the margins of older Holuhraun lavas. Black points show epicentres of earthquakes in the dyke extending between Bárðarbunga central volcano and the Holuhraun eruption site (data from Ágústsdóttir et al. 2016). c Propagation of pre-eruptive seismicity between

depths being tightly concentrated between 5 and $7 \mathrm{~km}$ along the entire $48 \mathrm{~km}$ dyke path (Ágústsdóttir et al. 2016). On 29 August, a fissure eruption commenced at the site of vents previously active during two older eruptions dated at 1797 and c. 1862-1864 AD (Hartley and Thordarson 2013). Following a period of 2-3 weeks of intense activity with magma discharge rates up to $8 \times 10^{5} \mathrm{~kg} \mathrm{~s}^{-1}$ (Gíslason et al. 2015), both the lava mass flow rate at Holuhraun and the rate of caldera subsidence at Bárðarbunga decreased exponentially until the eruption ended after 181 days of activity (Gudmundsson et al. 2016). The total volume of caldera subsidence, $1.8 \pm 0.2 \mathrm{~km}^{3}$, is comparable with a combination of the intruded magma volume $\left(0.5 \pm 0.1 \mathrm{~km}^{3}\right)$ and the total erupted magma output from the Holuhraun vents $\left(\sim 1.44 \mathrm{~km}^{3}\right.$; Pedersen et al. 2017). Three small ice cauldrons formed along the dyke path probably indicate the sites of
Bárðarbunga and the eruption site, modified after Ágústsdóttir et al. (2016). Dyke propagation phases are shaded in grey, and eruption periods shaded in orange. $\mathbf{d}$ Subsidence in the centre of Bárðarbunga caldera and the evolution of the subsidence volume, modified after Gudmundsson et al. (2016). Black circles indicate samples used in this study and their date of eruption

small subglacial eruptions (Reynolds et al. 2017), which are not included in this erupted volume estimate. Both seismic and geodetic observations are consistent with the magma erupted at Holuhraun being fed by a lateral dyke extending over $45 \mathrm{~km}$ from Bárðarbunga central volcano (Sigmundsson et al. 2015; Ágústsdóttir et al. 2016; Gudmundsson et al. 2016). Here, we interrogate the link between Bárðarbunga and Holuhraun using an extensive melt inclusion dataset.

\section{Samples and analytical methods}

Fresh, glassy samples of magmatic tephra were collected at regular intervals during the Holuhraun eruption. The ten samples selected for this study span the entire course of the eruption (Fig. 1; Table 1). Nine samples consist of proximal 
Table 1 Tephra samples from the 2014-2015 Holuhraun eruption analysed in this study

\begin{tabular}{llllll}
\hline Sample & Date of collection & Host macrocrysts & Melt inclusions & Embayments & Matrix glasses \\
\hline H14 & 31 Aug 2014 & plg, olv & $39(+5)$ & $1(+1)$ & $3(+2)$ \\
JG-040914-02 & 04 Sep 2014 & plg & 3 & & 1 \\
WM-1498-1 & 08 Sep 2014 & plg & 8 & 1 \\
JAS-130914-001 & 13 Sep 2014 & plg, olv, cpx & $13(+3)$ & 1 & 1 \\
AH-170914 & 17 Sep 2014 & plg & 3 & \\
CJG-230914-01 & 23 Sep 2015 & plg & 6 & \\
PDJJ-081014-02 & 08 Oct 2014 & plg & 8 & 1 \\
MSR-291014-3 & 20 Oct 2014 & plg & & & 2 \\
MSR-121114 & 12 Nov 2014 & plg & 4 & 1 \\
EI-220115-01 & 22 Jan 2015 & plg, olv & 15 & $2(+1)$ & $13(+2)$ \\
Total & & & $99(+8)$ & 2 \\
\hline
\end{tabular}

For each sample, the melt inclusion-bearing host macrocryst phases are indicated alongside the number of melt inclusions, embayments and matrix glasses analysed by SIMS. Numbers in parentheses show repeat analyses used to assess melt inclusion homogeneity and monitor analytical reproducibility tephra fall collected near the main eruptive vent, and are known to have erupted within 2 days of the date of collection. The tenth sample consists of glassy scoria clasts from the flanks of Baugur that were likely deposited up to 2 weeks prior to the date of collection.

Plagioclase, olivine and clinopyroxene macrocrysts in the size range $250-3000 \mu \mathrm{m}$ were hand-picked from crushed tephra samples, mounted in epoxy resin, and polished to expose glassy melt inclusions at the surface.

Volatile $\left(\mathrm{H}_{2} \mathrm{O}, \mathrm{F}\right.$, and $\left.\mathrm{Cl}\right)$, light lithophile, trace and rareearth elements were analysed in 99 melt inclusion glasses (88 hosted in plagioclase, 7 in olivine, and 4 in clinopyroxene), 2 glassy embayments, and 13 matrix glasses (Table 1) by secondary ion mass spectrometry (SIMS) using the Cameca ims-4f instrument at the University of Edinburgh. $\mathrm{CO}_{2}$ was also measured prior to performing the trace element analyses. Precision and accuracy for the trace element analyses were monitored by repeat analyses of standards NIST-SRM610, BCR-2G, KL2-G, and GSD-1G. $1 \sigma$ accuracy was consistently $10 \%$ or better. Precision was generally better than $\pm 2 \%$ for trace elements in high abundance (e.g., $\mathrm{La}, \mathrm{Sr}$, and $\mathrm{Zr}$ ) and $\pm 10 \%$ for trace elements in low abundance (e.g., $\mathrm{Yb}$ and $\mathrm{Lu}$ ). Following SIMS analyses, major, minor, and volatile ( $\mathrm{S}$ and $\mathrm{Cl}$ ) elements in the same inclusions were measured by electron microprobe (EPMA) using the Jeol JXA-8230 Superprobe at the University of Iceland. Volatile systematics and degassing behaviour of the Holuhraun magma are discussed in detail by Bali et al. (2018). Full details of analytical methods and compositional data are provided as supplementary material.

\section{Petrography of melt inclusions}

Both macrocrysts (here used to describe crystals $>0.5 \mathrm{~mm}$ in diameter) and microphenocrysts $(<0.5 \mathrm{~mm})$ from Holuhraun erupted products contain silicate melt inclusions (Fig. 2). The melt inclusions range from 15 to $174 \mu \mathrm{m}$ in their longest dimension. Most are spherical or elliptical in cross section; a small number have irregular or elongate geometries. Spherical melt inclusions are most commonly situated in macrocryst and microphenocryst cores (Fig. 2a, d) and can be regarded as primary melt inclusions. Irregular-shaped melt inclusions are present in different textural positions. Some are situated in macrocryst cores (Fig. 2b) or within growth zones (Fig. 2c): these are interpreted as texturally primary inclusions, trapped at different stages of mineral growth. Irregular-shaped inclusions are also observed along healed fractures of macrocrysts (Fig. 2c) and are regarded as secondary or pseudosecondary inclusions according to the nomenclature of Roedder (1984). Most secondary and pseudosecondary inclusions are less than $15 \mu \mathrm{m}$ in diameter, and too small to be analysed by ion microprobe (Fig. S3). It was not possible to determine the genetic relationship between the melt inclusion and host crystal from petrographic observations in some crystal fragments.

\section{Results}

\section{Major elements}

Measured melt inclusion compositions in all host minerals lie between 5.14 and $11.91 \mathrm{wt} \% \mathrm{MgO}$ (average $8.07 \mathrm{wt}$. $\mathrm{MgO}$; Fig. S1). However, major element compositions of melt inclusions can be greatly affected by post-entrapment crystallization (PEC) of the host mineral onto the inclusion walls. For olivine-hosted inclusions, PEC causes a reduction

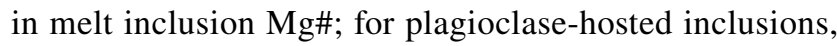
$\mathrm{Mg} \#$ is unaffected, but $\mathrm{Al}_{2} \mathrm{O}_{3}$ and $\mathrm{CaO}$ are removed from the inclusion by PEC. Olivine-hosted inclusions were corrected 
Fig. 2 Petrographic characteristics of silicate melt inclusions in macrocrysts and microphenocrysts from the 2014-2015 Holuhraun eruption. a Randomly distributed spherical primary melt inclusions (MI) in a clinopyroxene (cpx) macrocryst surrounded by groundmass glass (gm); sample JAS-130914-001. b Vermicular primary melt inclusions in a plagioclase (plg) macrocryst; sample MSR-291014-3. c Primary melt inclusions in a plagioclase macrocryst rim; sample AH-170914. A trail of pseudosecondary melt inclusions is located along a healed fracture in the macrocryst core. d Back-scattered electron image of a primary melt inclusion in an olivine (olv) microphenocryst in sample EI-220115. The circular feature in the melt inclusion is a pit formed during SIMS analysis
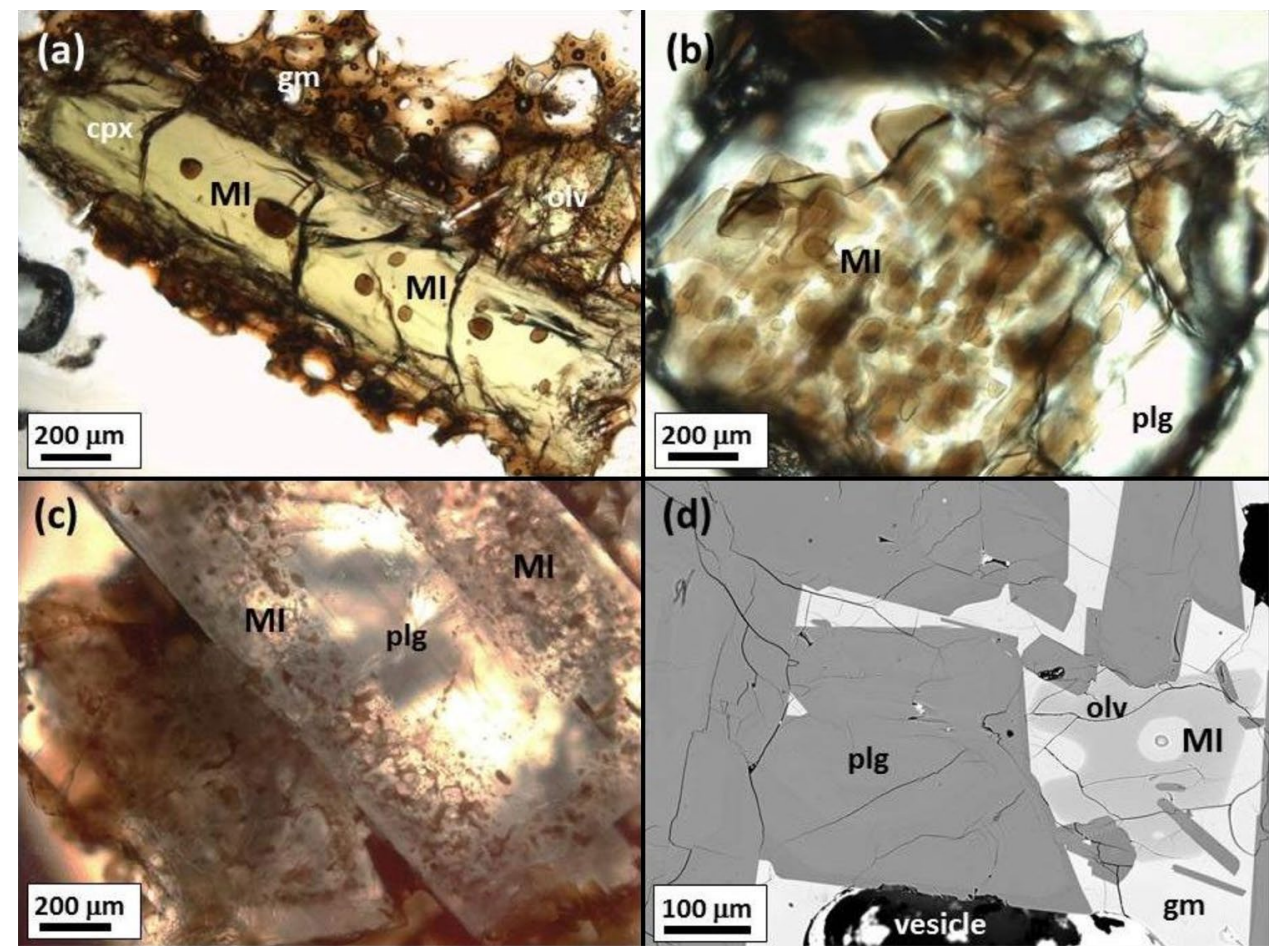

for PEC using Petrolog3 (Danyushevsky and Plechov 2011), following the methodology of Danyushevsky et al. (2000).

There is no universally accepted procedure for correcting PEC in plagioclase-hosted melt inclusions. We therefore employed an empirical correction based on $\mathrm{TiO}_{2}-\mathrm{Al}_{2} \mathrm{O}_{3}$ systematics, similar to that of Neave et al. (2017). $\mathrm{TiO}_{2}$ is incompatible during the crystallization of all phases, whereas $\mathrm{Al}_{2} \mathrm{O}_{3}$ is the most modified component during $\mathrm{PEC}$ in plagioclase-hosted inclusions. The unmodified $\mathrm{Al}_{2} \mathrm{O}_{3}$ content of the plagioclase-hosted inclusions can therefore be estimated at a given $\mathrm{TiO}_{2}$ content based on the $\mathrm{TiO}_{2}-\mathrm{Al}_{2} \mathrm{O}_{3}$ relationship shown by Holuhraun and Bárðarbunga (Breddam 2002; Óladóttir et al. 2011; Neave et al. 2014) glass compositions $\left(R^{2}=0.67, p \ll 0.01\right)$. Melt inclusions were corrected for PEC by incrementally adding the host plagioclase composition back into the inclusion until its $\mathrm{TiO}_{2}-\mathrm{Al}_{2} \mathrm{O}_{3}$ systematics were consistent with Icelandic tholeiitic glasses: that is, until $\mathrm{Al}_{2} \mathrm{O}_{3}$ in the inclusion reached the value predicted from $\mathrm{TiO}_{2}$ based on a linear regression through the glass data (Figs. S1, S2). Following this procedure, $89 \%$ of the plagioclase-hosted inclusions had $\mathrm{Kd}_{\mathrm{Ab}-\mathrm{An}}^{\mathrm{plg} \text {-liq }}$ within the range $0.27 \pm 0.11$ relevant for melt-plagioclase equilibration above $1050{ }^{\circ} \mathrm{C}$ (Putirka 2008). Eleven inclusions, one hosted in $\mathrm{An}_{81}$ and ten in $\mathrm{An}_{>84}$ plagioclases, had $\mathrm{Kd}_{\mathrm{Ab} \text {-An }}^{\text {plg-liq }}$ lower than the equilibrium range. Applying any further PEC correction to these inclusions to comply with the equilibrium criterion resulted in unrealistically high $\mathrm{Al}_{2} \mathrm{O}_{3}$ contents compared with Bárðarbunga and other Icelandic tholeiitic glasses.
Similarly unrealistic melt compositions were obtained by Neave et al. (2017) when applying equilibrium-based PEC corrections to high-anorthite plagioclase-hosted inclusions from the nearby Grímsvötn volcanic system.

We conducted a further test for equilibrium by comparing the output from a plagioclase-melt thermometer [Eq. 24a of Putirka (2008); standard error of estimate (SEE) $\left.\pm 36{ }^{\circ} \mathrm{C}\right]$ with an independent melt thermometer [Eq. 16 of Putirka (2008); SEE $\pm 26^{\circ} \mathrm{C}$ ]. Both equations require the input of a pressure term. For any given inclusion, varying the input pressure between 1 and 5 kbar produced temperature differences up to $30^{\circ}$ in the case of the plagioclase-melt thermometer, and up to $16^{\circ}$ for the melt thermometer. Since these differences are within the SEE of the respective thermometers, we chose to assume a uniform input pressure of $3 \mathrm{kbar}$. The thermometers returned temperatures within $\pm 20^{\circ} \mathrm{C}$ of one another for all but nine plagioclase-hosted inclusions, including the six most primitive inclusions. Additional PEC correction was applied to these inclusions such that the thermometers returned temperatures within $\pm 20^{\circ} \mathrm{C}$, while taking care not to over-correct the inclusion compositions and violate the $\mathrm{TiO}_{2}-\mathrm{Al}_{2} \mathrm{O}_{3}$ and $\mathrm{MgO}-\mathrm{Al}_{2} \mathrm{O}_{3}$ systematics of Icelandic tholeiitic glasses. After this PEC correction, the six most primitive inclusions have slightly lower $\mathrm{FeO}$, and higher $\mathrm{CaO}$, than the only published primitive glass analyses from the Bárðarbunga volcanic system measured at Kistufell (Breddam 2002) (Fig. 3). However, it was not possible to match simultaneously all the PEC-corrected major element 
(a)

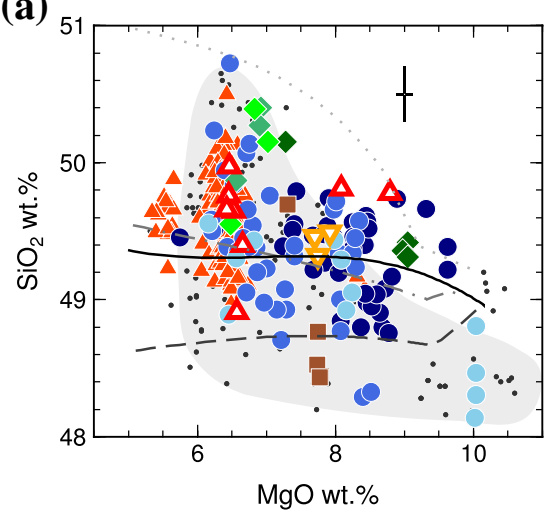

(c)

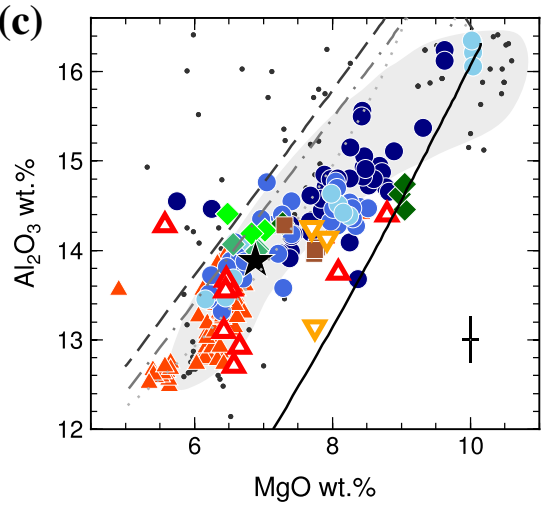

(b)

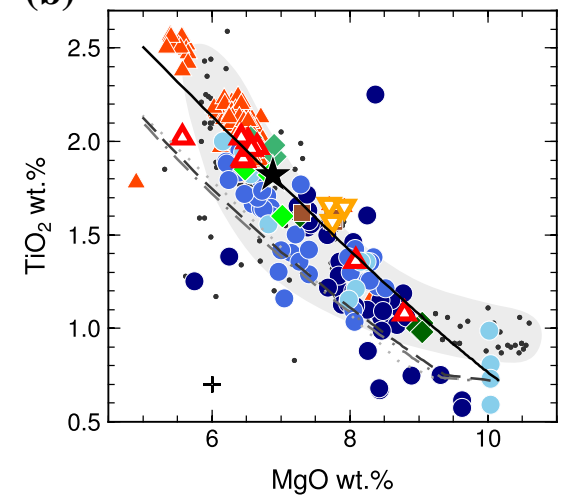

(d)

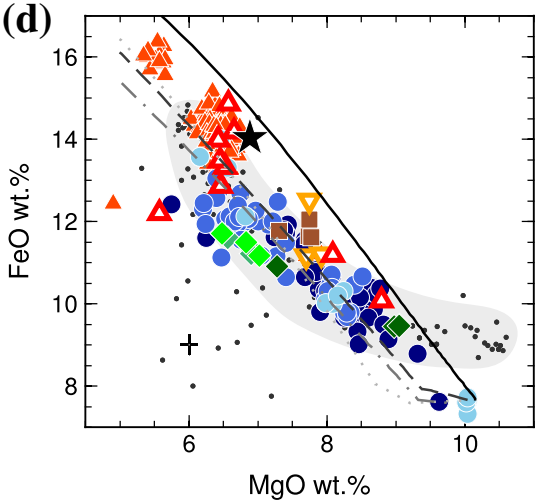

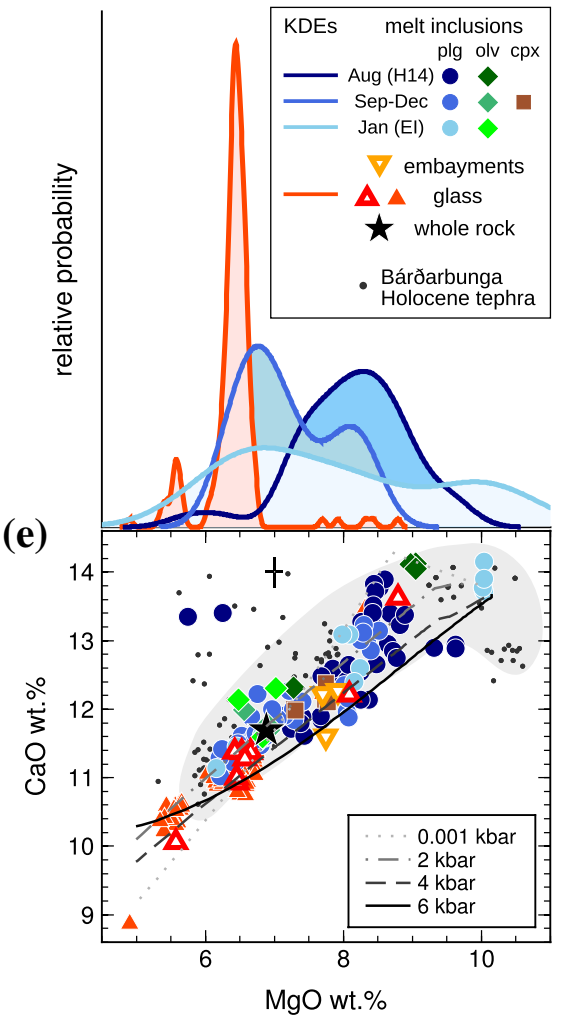

Fig. 3 Major elements of melt inclusions, embayments, and glasses from the 2014-2015 Holuhraun eruption. Melt inclusion compositions have been corrected for post-entrapment crystallization. Small red triangles show glass compositions; large open red triangles show the glass samples in which trace elements were analysed. Black stars show the mean whole-rock composition. Grey-shaded fields show typical Holocene tephra glass compositions from the Bárðarbunga volcanic system; small black circles are Bárðarbunga tephra analyses from Thordarson et al. (1998) and Óladóttir et al. (2011). Error bars are $1 \sigma$. Solid and dashed lines show fractional crystallization models calculated for the mean primitive melt inclusion composition, calculated over a range of pressures using the mineral-melt equilibria of Langmuir et al. (1992). The kernel density estimates above panel e show the distribution of measured $\mathrm{MgO}$ contents for Holuhraun matrix glasses (red), melt inclusions in samples collected in August 2014, (dark blue), melt inclusions from September-December 2014 (mid blue), and melt inclusions from January 2015 (light blue)

and embayments contain between 9.05 and $6.48 \mathrm{wt} \% \mathrm{MgO}$. The embayments and PEC-corrected inclusions are compositionally similar to Holocene tephras erupted from the Bárðarbunga volcanic system (Óladóttir et al. 2011) (Fig. 3).

Matrix glass compositions were measured immediately adjacent to large plagioclase macrocrysts in sample H14, and in vesicular tephra glass shards for all other samples. Three glasses measured adjacent to large plagioclases in sample H14 are compositionally heterogeneous, containing 5.57, 8.09 , and $8.79 \mathrm{wt} \% \mathrm{MgO}$. The vesicular tephra glasses cluster around $6.5 \mathrm{wt} \% \mathrm{MgO}$, and are compositionally similar to the most evolved melt inclusions (Fig. 3). They are also compositionally identical to vesicular tephra glass shards produced throughout the Holuhraun eruption $(n=172$; Gudmundsson et al. 2016). In the following discussion, we assume that the mean vesicular glass composition is representative of the Holuhraun carrier melt. At atmospheric pressure, liquidus temperature of $1170_{-5}^{+10}{ }^{\circ} \mathrm{C}$ (Gudmundsson 
et al. 2016), and oxygen fugacity of FMQ+0.2 (Bali et al. 2018 ), this composition is in equilibrium with $\mathrm{Fo}_{72}$ olivine, $\mathrm{An}_{69}$ plagioclase, and $\mathrm{Mg \#}=75$ clinopyroxene.

\section{Trace elements}

Trace element compositions in all melt inclusions were corrected for PEC using the partition coefficients collated by O'Neill and Jenner (2012). The PEC-corrected inclusions have very similar average trace element concentrations to the Holuhraun glasses and whole-rock samples, with melt inclusions having slightly lower average trace element abundances than the average glass and whole rock (Fig. 4a). The trace element concentrations measured in melt inclusions, glasses, and whole rocks from the 2014-15 eruption are near-identical to those from the two older eruptions from the Holuhraun vents (Hartley and Thordarson 2013). All trace elements are significantly variable at the $99 \%$ confidence level with signal-to-noise ratios $\sigma_{\mathrm{t}} / \sigma_{\mathrm{r}}$ greater than 1.71 $\left(3.22 \leq \sigma_{\mathrm{t}} / \sigma_{\mathrm{r}} \leq 10.62\right)$, where $\sigma_{\mathrm{t}}$ is the true variability within a sample set and $\sigma_{\mathrm{r}}$ is an estimate of analytical error (Maclennan et al. 2003).

Strontium anomalies in melt compositions can be quantified by the parameter $\mathrm{Sr} / \mathrm{Sr}^{*}=\mathrm{Sr}_{n} /\left(\mathrm{Ce}_{n} \times \mathrm{Nd}_{n}\right)^{0.5}$, where the subscript $n$ indicates chondrite-normalised values. $\mathrm{Sr} / \mathrm{Sr} *$ in the Holuhraun melt inclusions correlates positively with
$\mathrm{MgO}$, which is consistent with crystallization of a plagioclase-bearing assemblage: this is evident in the slight negative $\mathrm{Sr}$ anomalies in matrix glasses and some melt inclusions (Fig. 4a) which are indicative of plagioclase crystallization from the melt prior to inclusion trapping. Large positive $\mathrm{Sr} /$ Sr* anomalies, accompanied by low La concentrations and low $\mathrm{La} / \mathrm{Yb}$, have been suggested to be indicative of dissolution-reaction-mixing (DRM) processes involving plagioclase dissolution into the melt prior to inclusion trapping (e.g., Danyushevsky et al. 2003). Icelandic tholeiites with similar Sr concentrations to the Holuhraun melt inclusions (120-190 ppm Sr) are expected to have $\mathrm{Sr} / \mathrm{Sr} *$ between 0.5 and 1.9 (Gurenko and Sobolev 2006). Of the 99 Holuhraun inclusions analysed, 59 have $\mathrm{Sr} / \mathrm{Sr}^{*}<1$ and 91 have $\mathrm{Sr} /$ Sr* $<1.5$ (Fig. 4b). While DRM processes are predicted to produce a negative correlation between $\mathrm{La} / \mathrm{Yb}$ and $\mathrm{Sr} / \mathrm{Sr} *$, there is no correlation between these ratios $\left(R^{2}=0.02\right)$ in the Holuhraun inclusions. Furthermore, while the inclusions with $\mathrm{Sr} / \mathrm{Sr} *>1.5$ have low La contents of 2.49-3.52 ppm, they are not systematically associated with low $\mathrm{La} / \mathrm{Yb}$ : the inclusions with $\mathrm{Sr} / \mathrm{Sr}^{*}>1.5$ have $1.51<\mathrm{La} / \mathrm{Yb}<3.90$, compared with $1.43<\mathrm{La} / \mathrm{Yb}<5.14$ in the remainder of the melt inclusion suite. These observations indicate that while DRM processes may have had a minor effect on a small number of Holuhraun melt inclusions, it is not the dominant control on trace element variability in these inclusions.

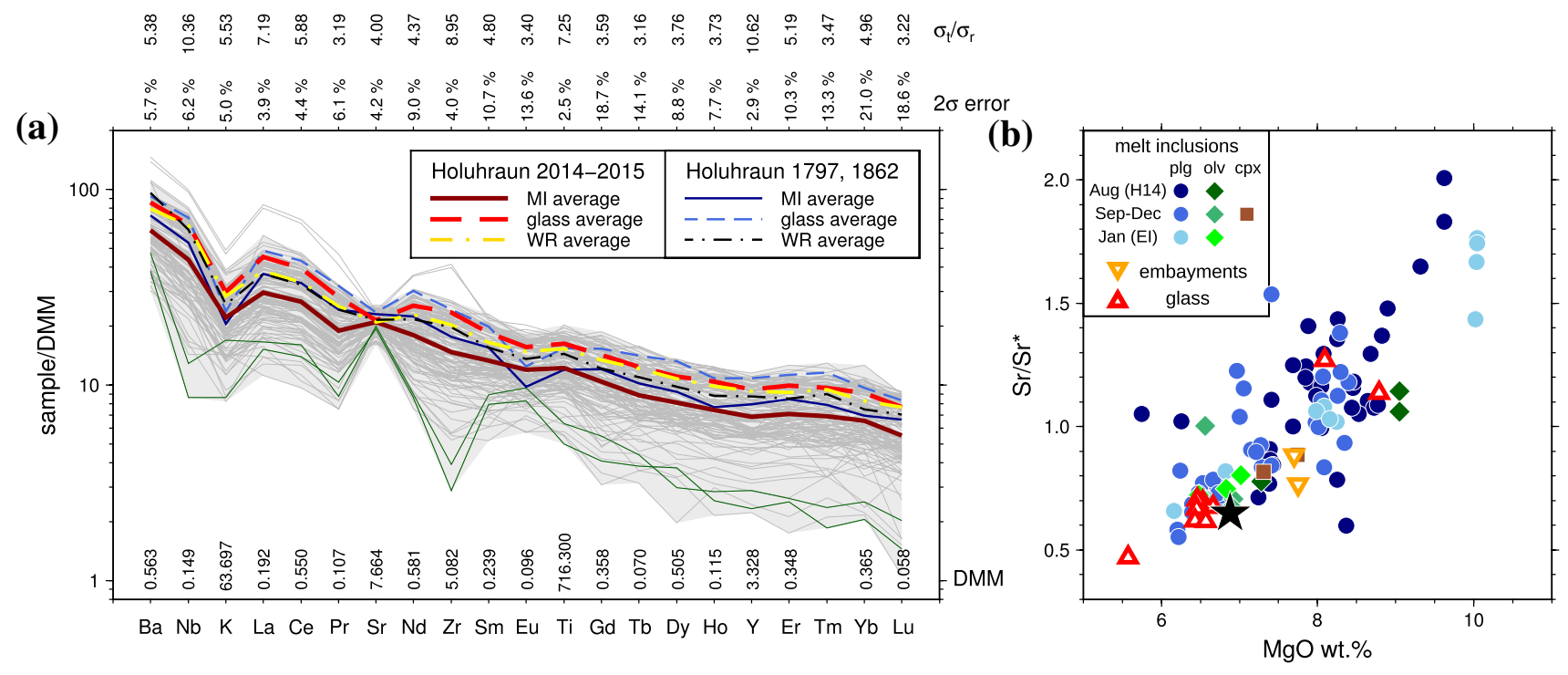

Fig. 4 a Multi-element diagram for Holuhraun melt inclusions and glasses. Concentrations are normalised to depleted MORB mantle (Workman and Hart 2005) with normalisation values shown along the bottom and $2 \sigma$ errors shown along the top of the plot. The shaded area shows the range of melt inclusion and glass compositions; individual inclusions are shown by the thin grey lines. Variability in melt inclusion compositions is reported as signal-to-noise ratios $\left(\sigma_{\mathrm{t}} / \sigma_{\mathrm{r}}\right)$ for each element, shown at the top of the plot. Dark green lines show two melt inclusions with moderate depletions in high field strength elements $(\mathrm{Zr} / \mathrm{Y}<2.1)$, visible by their negative $\mathrm{Zr}$ anomalies. Melt inclusions and glasses from the 2014-2015 eruption have near-identical average compositions to older eruptions at Holuhraun in 1797 and 1862 (data from Hartley and Thordarson 2013). b $\mathrm{Sr} / \mathrm{Sr} *$ vs. $\mathrm{MgO}$ in Holuhraun whole-rock (black star), melt inclusions, embayments, and glasses 
Holuhraun matrix glasses have a mean La/Yb of $2.58 \pm 0.77(1 \sigma)$ (Fig. 5). The high standard deviation is due to the heterogeneous glass compositions measured around large macrocrysts in sample $\mathrm{H} 14$. The $\mathrm{H} 14$ glasses range in $\mathrm{La} / \mathrm{Yb}$ from 1.68 to 4.36 , and $\mathrm{La} / \mathrm{Yb}$ in these glasses is inversely correlated with $\mathrm{MgO}$. Considering only the vesicular glass shards, the mean $\mathrm{La} / \mathrm{Yb}$ is $2.34 \pm 0.13$.

The mean melt inclusion $\mathrm{La} / \mathrm{Yb}$ is $2.44 \pm 0.59(1 \sigma)$. Concentrations of incompatible trace elements such as $\mathrm{La}$ and $\mathrm{Yb}$ are negatively correlated with PEC-corrected melt inclusion $\mathrm{MgO}$ contents, as well as with host macrocryst compositions (Fig. S4). Most melt inclusion compositions cluster around the mean melt inclusion and glass $\mathrm{La} / \mathrm{Yb}$ (Fig. 5; Fig. S5), although a small number of somewhat

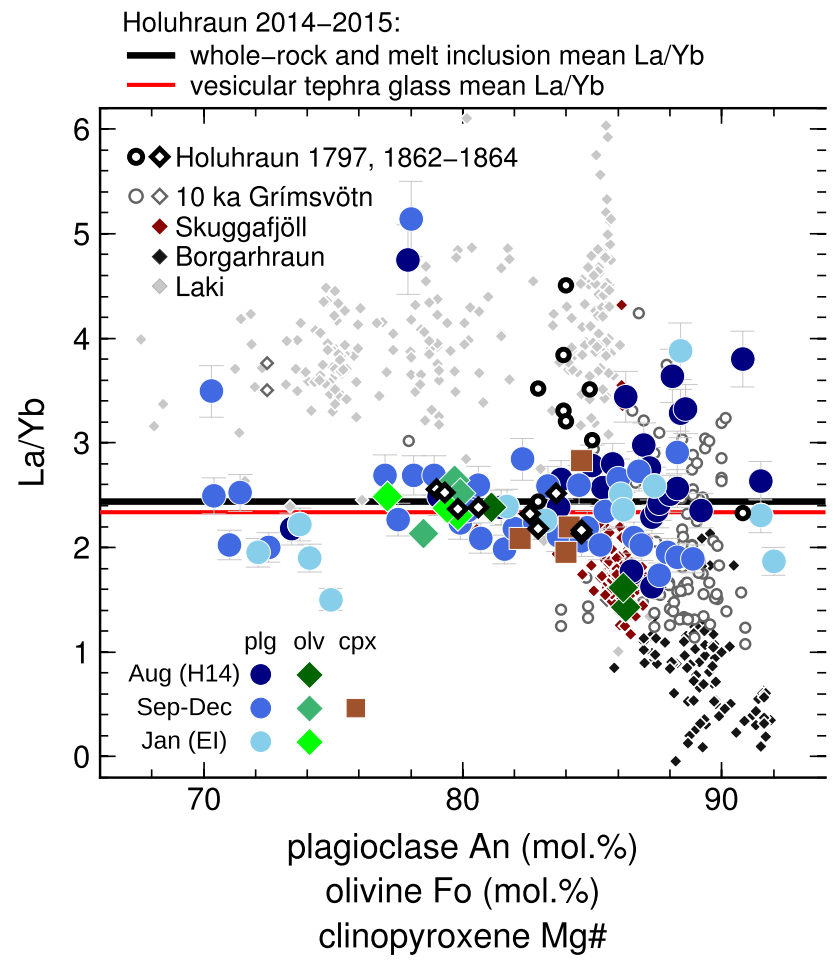

Fig. $5 \mathrm{La} / \mathrm{Yb}$ vs. host macrocryst composition for Holuhraun melt inclusions. Error bars are $2 \sigma$. In plagioclase-hosted inclusions, variability in $\mathrm{La} / \mathrm{Yb}$ decreases with decreasing host anorthite content. This is interpreted as evidence of concurrent mixing and crystallization of diverse primary melt compositions supplied to the Holuhraun magmatic system. As crystallization and mixing progress, compositional variability collapses to the mean melt inclusion and glass values, shown by the black and red lines, respectively. Note that the mean whole-rock $\mathrm{La} / \mathrm{Yb}$ is identical to the mean melt inclusion $\mathrm{La} / \mathrm{Yb}$. Similar relationships between melt inclusion $\mathrm{La} / \mathrm{Yb}$ and host mineral composition are observed in olivine-hosted melt inclusions from Laki (Neave et al. 2013; Hartley et al. 2014), Skuggafjöll (Neave et al. 2014) and Borgarhraun (Maclennan et al. 2003), and olivine- and plagioclase-hosted melt inclusions from older eruptions at Holuhraun (Hartley and Thordarson 2013). Compositions of plagioclase-hosted melt inclusions from the $10 \mathrm{ka}$ Grímsvötn tephra series (Neave et al. 2015) are shown for comparison more enriched inclusions are hosted in $\mathrm{An}_{>85}$ plagioclases. The two most enriched inclusions $(\mathrm{La} / \mathrm{Yb}>4.7)$ are hosted in $\mathrm{An}_{\sim 78}$ plagioclases, while the three most depleted inclusions $(\mathrm{La} / \mathrm{Yb}<1.8)$ are hosted in two $\mathrm{Fo}_{86}$ olivines and one $\mathrm{An}_{75}$ plagioclase (Fig. 5). Two inclusions, hosted in $\mathrm{An}_{86}$ and $\mathrm{An}_{88}$ plagioclases, are moderately depleted in high field strength elements with $\mathrm{Zr} / \mathrm{Y}<2.1$ (Fig. 4a), and are similar in composition to HFSE-depleted inclusions from the $10 \mathrm{ka}$ Grímsvötn tephra series (Neave et al. 2015). These inclusions have $\mathrm{La} / \mathrm{Yb}=3.44$ and 3.88 .

\section{Light lithophile elements}

Boron contents in Holuhraun melt inclusions range from 0.16 to $1.03 \mathrm{ppm}$ (mean $0.55 \pm 0.17$ ). Boron is negatively correlated with $\mathrm{MgO}$, although a sub-population of inclusions, mainly from sample $\mathrm{H} 14$, have higher B contents at a given $\mathrm{MgO}$ than the main population (Fig. 6a). The matrix glasses range from 0.43 to 0.94 ppm $\mathrm{B}$, with the highest and lowest B contents found in the glasses from sample H14. The vesicular tephra glasses contain $0.74 \pm 0.04$ ppm B (Fig. 6a).

The mean Li content of the Holuhraun matrix glasses is $4.03 \pm 1.58 \mathrm{ppm}$, or $4.87 \pm 0.94 \mathrm{ppm}$ if only the vesicular tephra glasses are considered. The melt inclusions can be divided into two sub-populations with $\mathrm{Li} \leq 8$ and $\mathrm{Li}>8$ ppm (Fig. 6b). In the low-Li population, measured Li contents range from 1.13 to 6.57 , and $\mathrm{Li}$ is weakly negatively correlated with $\mathrm{MgO}\left(R^{2}=0.48\right)$. Melt inclusions in the high-Li population are hosted exclusively in plagioclase, and contain 8.18-18.12 ppm Li. These inclusions show no correlation between $\mathrm{Li}$ and $\mathrm{MgO}$ : $\mathrm{Li}$ is highly variable across the full compositional range (Fig. 6b).

\section{Discussion}

\section{Fractional crystallization modelling}

To test the ability of a single liquid line of descent (LLD) to reproduce the full suite of Holuhraun melt inclusion compositions, fractional crystallization models were calculated using Petrolog3 (Danyushevsky and Plechov 2011). Forward crystallization models were calculated for the mean composition of the three most primitive melt inclusions (10.0 wt\% $\mathrm{MgO}$ ) and for the mean composition of six inclusions with $\mathrm{MgO}$ from 8.72 to $9.05 \mathrm{wt} \%$. We also tested reverse fractional crystallization models, taking the average vesicular tephra glass composition as representative of the Holuhraun carrier melt. Models were run to simulate crystallization at pressures of $0.001,2,4$, and $6 \mathrm{kbar}$, which encompass likely pressures of crystallization within magmatic systems in Iceland's Eastern Volcanic Zone (EVZ) (Neave and Putirka 2017), at an oxygen fucacity of FMQ + 0.2. Forward and 

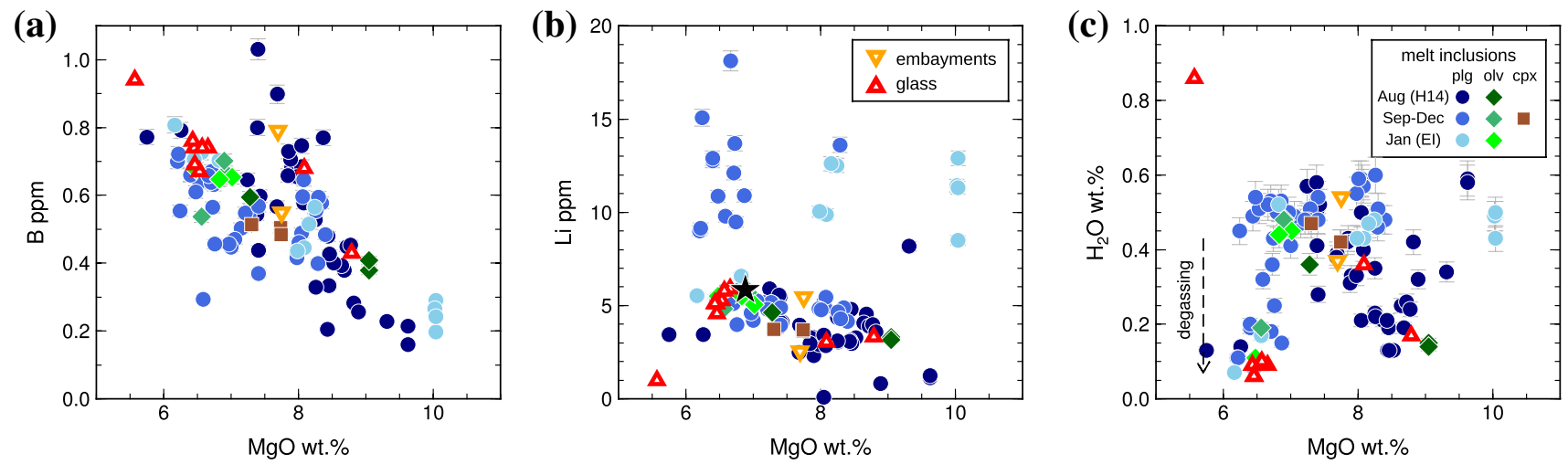

Fig. 6 Light lithophile element and $\mathrm{H}_{2} \mathrm{O}$ concentrations of melt inclusions, embayments, and glasses from the 2014-2015 Holuhraun eruption. Melt inclusions have been corrected for post-entrapment crystallization. a Boron behaves as an incompatible trace element in the Holuhraun magma. A subset of inclusions, mostly from sample H14, have higher $\mathrm{B}$ contents at a given $\mathrm{MgO}$ content than the main population of inclusions. b Lithium appears to behave as an incompatible trace element in most melt inclusions. A sub-population of inclusions

reverse crystallization calculations were tested using a range of mineral-melt equilibrium models (Danyushevsky 2001; Langmuir et al. 1992; Gaetani and Watson 2002) for olivine, plagioclase, and clinopyroxene.

The calculated LLDs are sensitive to starting composition, pressure, and the choice of mineral-melt equilibrium models. In Fig. 3, we show LLDs calculated by forward crystallization of the primitive melt inclusion composition, using the mineral-melt equilibria of Langmuir et al. (1992) and with $\mathrm{Kd}_{\mathrm{Fe}-\mathrm{Mg}}^{\mathrm{ol}-\mathrm{liq}}$ modelled after Toplis (2005). Overall, the Holuhraun melt inclusion data are not well reproduced by any single LLD. We computed several forward and reverse crystallization models varying the choice of starting composition, pressure, and mineral-melt equilibria, and in no case did the model LLD perfectly reproduce the pattern of the Holuhraun data. Given the variability in melt inclusion major element oxide contents at any given $\mathrm{MgO}$, this is not a surprising result. Thus, while the compositional trends in Fig. 3 are broadly consistent with a dominant fractional crystallization control, we conclude that fractional crystallization alone is insufficient to explain the observed variability in melt inclusion compositions.

\section{Temporal evolution of melt inclusion compositions}

There is no evidence of temporal evolution in the Holuhraun whole rock or tephra glass compositions (Fig. S6). The kernel density estimates in Fig. 3e indicate that the most probable $\mathrm{MgO}$ content for inclusions from sample $\mathrm{H} 14$ is higher than for inclusions collected later in the eruption (see also Fig. S7). However, the mean $\mathrm{MgO}$ content of the have high Li concentrations $>8$ ppm. $\mathbf{c} \mathrm{H}_{2} \mathrm{O}$ contents in Holuhraun melt inclusions show no systematic relationship with $\mathrm{MgO}$, and cannot be explained by simple fractional crystallization. A small population of more evolved melt inclusions have either trapped a partially degassed melt or experienced post-entrapment dehydration. Vesicular tephra glasses have experienced syn-eruptive degassing and contain $0.07-0.08 \mathrm{wt} \% \mathrm{H}_{2} \mathrm{O}$

H14 melt inclusions is $8.13 \pm 0.81 \mathrm{wt} \%(1 \sigma)$, which is statistically indistinguishable from the $7.36 \pm 0.99 \mathrm{wt} \% \mathrm{MgO}$ for inclusions in samples collected between September and December 2014. Likewise, we find no statistically significant time-dependent variability in incompatible trace element ratios such as $\mathrm{La} / \mathrm{Yb}$ in the Holuhraun melt inclusions (Fig. S9a). Over $40 \%$ of the inclusions analysed were from sample $\mathrm{H} 14$, so it is possible that any apparent temporal evolution in the melt inclusion compositions (or lack thereof) reflects a sampling bias that might not persist if more samples were analysed. We note that sample EI, collected on day 145 of the eruption, contains the most primitive inclusions at 10.0 $\mathrm{wt} \% \mathrm{MgO}$ as well some of the most evolved inclusions at 6.2-6.9 wt\% $\mathrm{MgO}$ (Fig. 3e).

\section{Lithium in melt inclusions}

Lithium appears to behave as an incompatible trace element in the main population of Holuhraun melt inclusions with $\mathrm{Li}<8$ ppm (Fig. 6b). However, no such relationship can be inferred for the high- $\mathrm{Li}(\mathrm{Li}>8 \mathrm{ppm})$ population. It is possible that the variability in melt inclusion Li content is time dependent: only one inclusion from sample H14 falls within the high-Li population, while the remainder are found in samples collected after the initial stages of the eruption (Figs. S8, S9b). It is very difficult to relate the high-Li population to the low-Li population by a simple fractional crystallization process. Thus, if the melt inclusions preserve the light lithophile element contents of their carrier melts at the time of inclusion trapping, this unusual compositional distribution could reflect either heterogeneous Li distribution in the Holuhraun melt, or post-entrapment modification of Li. 
Post-entrapment modification of melt inclusion Li contents can be assessed using the ratio $\mathrm{Li} / \mathrm{Yb}$. These trace elements are similarly incompatible in basaltic melts; thus, Li/ $\mathrm{Yb}$ is expected to remain constant during fractional crystallization. Mid-ocean ridge basalt (MORB) glasses have Li/ Yb values of $\sim 1.7$ (Jenner and O'Neill 2012). While typical ocean island basalt (OIB) glasses have mean $\mathrm{Li} / \mathrm{Yb}$ values slightly greater than 1.7 (Ryan and Langmuir 1987), olivine-hosted melt inclusions from Kilauea, Hawaii, indicate that primary $\mathrm{Li} / \mathrm{Yb}$ values in OIB range between 1.0 and 2.5 (Edmonds 2015). Seventy of the 77 Holuhraun melt inclusions with $\mathrm{Li}$ concentrations $<8 \mathrm{ppm}$ have $\mathrm{Li} / \mathrm{Yb}$ values within the expected range for OIB (Fig. 7a), with no systematic variability between $\mathrm{Li} / \mathrm{Yb}$ and host macrocryst composition (Fig. 7b). Lithium in these inclusions therefore appears to be unaffected by post-entrapment modification. In contrast, all but two of the 22 high-Li inclusions have $\mathrm{Li} / \mathrm{Yb}$ greater than the expected OIB values (Fig. 7a), suggesting that high-Li was not a primary feature of the trapped melt compositions. Furthermore, the maximum Li/Yb decreases with decreasing host plagioclase anorthite content (Fig. 7b), but increases continuously with eruption progress (Fig. S9).

For the high-Li inclusions, there is no statistically significant correlation between $\mathrm{Li}$ and any other incompatible or volatile element, including $\mathrm{H}_{2} \mathrm{O}$ (Figs. S6, S8). It is therefore unlikely that high $\mathrm{Li}$ concentrations resulted from the trapping of incompatible element-enriched boundary layers surrounding rapidly growing crystals (cf. Baker et al. 2008). High Li contents in melt inclusions could be achieved by diffusive exchange between an initially low-Li inclusion and

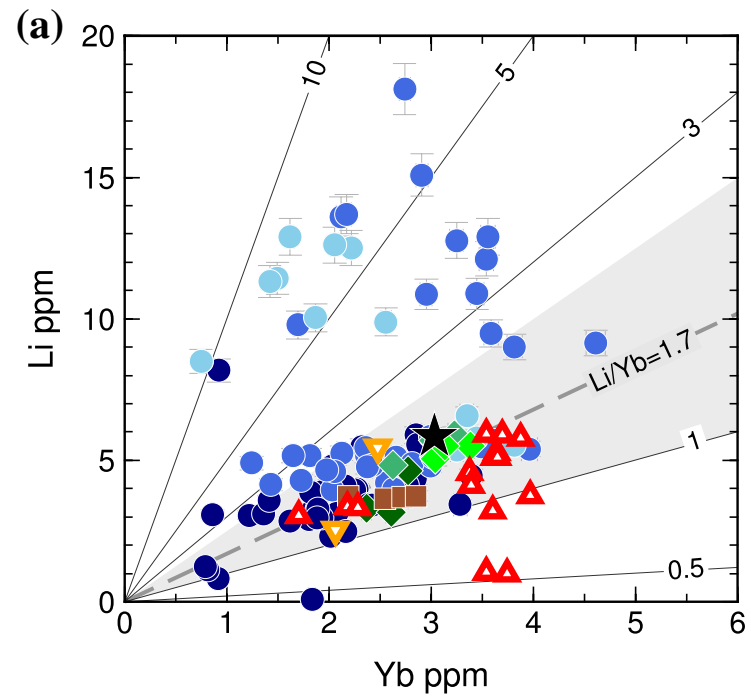

Fig. 7 a $\mathrm{Li}$ vs. $\mathrm{Yb}$ for melt inclusions and glasses from Holuhraun, using the same symbols as Fig. 3. Lines show contours of constant $\mathrm{Li} / \mathrm{Yb}$. MORB is typified by $\mathrm{Li} / \mathrm{Yb} \sim 1.7$, and the grey-shaded area shows $1.0<\mathrm{Li} / \mathrm{Yb}<2.5$ as obtained for olivine-hosted melt inclusions from Kilauea (Edmonds 2015). Most melt inclusions fall within this a Li-enriched carrier melt: at magmatic temperatures, $\mathrm{Li}^{+}$ diffusion through plagioclase is approximately two orders of magnitude faster than $\mathrm{H}^{+}$(Giletti and Shanahan 1997). However, the maximum measured $\mathrm{Li}$ in the Holuhraun matrix glass is $6 \mathrm{ppm}$, which is insufficient to produce highLi melt inclusions by diffusive re-equilibration. It is possible that Li was heterogeneously distributed within the carrier melt, allowing melt inclusions either to trap Li-enriched melt pockets or to undergo diffusive exchange with melt containing up to $18 \mathrm{ppm} \mathrm{Li}$. If this is the case, then the high-Li melt pockets would be expected to have degassed some $50 \%$ of their Li budget during ascent and eruption. While Li is generally considered to be a non-volatile element with a vapour-melt partition coefficient of less than 0.1 (Mather 2015, and references therein), investigations of trace metal degassing into the Holuhraun plume suggest that Li exhibited highly volatile behaviour during this eruption (Ilyinskaya et al. 2017). We therefore speculate that the highLi melt inclusions were trapped during crystallization in Lisupersaturated melt pockets, which subsequently degassed any excess $\mathrm{Li}$ at the vents.

\section{Concurrent mixing and crystallization in the Holuhraun magmatic system}

It has been shown that $\mathrm{La} / \mathrm{Yb}$ variability in olivine-hosted melt inclusions decreases with decreasing host forsterite content in the products of several Icelandic eruptions (e.g., Maclennan et al. 2003; Maclennan 2008; Neave et al. 2013; Hartley et al. 2014). This is interpreted as evidence

(b)

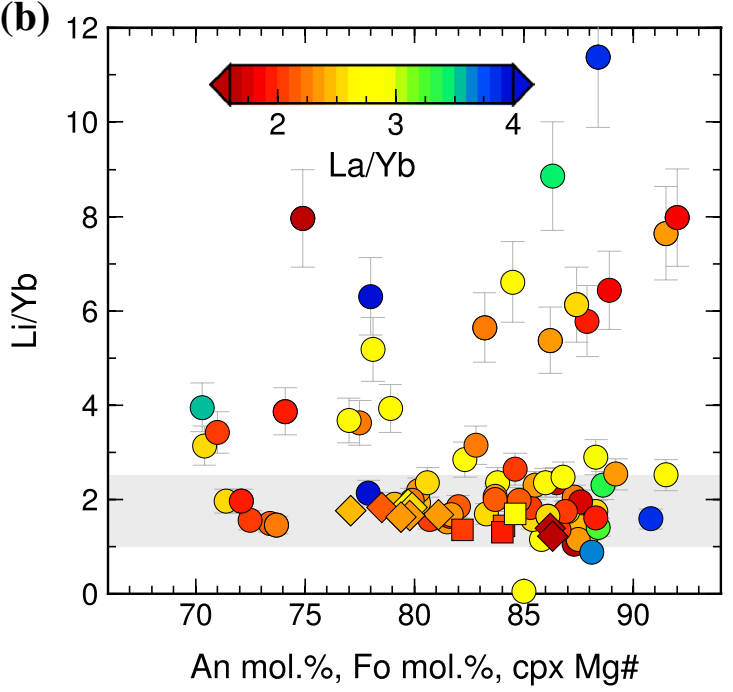

expected OIB range, with the exception of plagioclase-hosted inclusions with anomalously high $\mathrm{Li}>8 \mathrm{ppm}$ and some degassed matrix glasses. b Li/Yb vs. host macrocryst composition, coloured by La/Yb. The variability in $\mathrm{Li} / \mathrm{Yb}$ decreases with decreasing host plagioclase anorthite content 
of concurrent mixing and crystallization of diverse mantle melt compositions delivered to these magmatic systems (Maclennan 2008).

While melt inclusions from Holuhraun range in La/ $\mathrm{Yb}$ from 1.43 to 5.14, the most extreme enriched and depleted compositions are not found in the most primitive host crystals. For inclusions hosted in $\mathrm{An}_{\geq 82}$ macrocrysts, the minimum and maximum $\mathrm{La} / \mathrm{Yb}$ are 1.63 and 3.88, respectively, and the $1 \sigma$ standard deviation in $\mathrm{La} / \mathrm{Yb}$ for these inclusions is 0.53 . This is similar to the $1 \sigma$ standard deviation in $\mathrm{La} / \mathrm{Yb}$ for inclusions hosted in $\mathrm{Fo}_{\geq 86}$ olivines from Borgarhraun (0.57; Maclennan et al. 2003), but much lower than that of inclusions hosted in $\mathrm{Fo}_{\geq 81}$ olivines from Laki (0.98; Hartley et al. 2014). It is not straightforward to make direct comparisons between olivine- and plagioclase-hosted melt inclusion datasets, because the first appearance of these minerals on the liquidus is dependent on both primary melt composition and crystallization pressure. However, eruptions with higher mean $\mathrm{La} / \mathrm{Yb}$ are expected to have a higher dispersion in melt inclusion $\mathrm{La} /$ $\mathrm{Yb}$, even if the melt is better mixed (Maclennan 2008; Rudge et al. 2013). The fact that Holuhraun has a more enriched bulk composition than Borgarhraun, but has similar dispersion in melt inclusion $\mathrm{La} / \mathrm{Yb}$ leads us to suggest that the diversity of primary melt compositions supplied to the Holuhraun magmatic system was more limited than for Borgarhraun. Alternatively, the Holuhraun melt inclusion record we have accessed may not capture the earliest stages of mixing between diverse mantle melts: it is possible that the earliest stages of mixing and crystallization were captured by melt inclusions in high-forsterite olivines, which are notably absent in Holuhraun erupted products.

It is useful to compare the Holuhraun plagioclasehosted melt inclusion compositions with those from the 10 ka Grímsvötn tephra series (Neave et al. 2015), which is currently the only other extensive dataset of plagioclase-hosted melt inclusion compositions available for an Icelandic eruption. While Holuhraun and Grímsvötn melt inclusions have similar mean $\mathrm{La} / \mathrm{Yb}$ of 2.4 and 2.1, respectively, the Grímsvötn melt inclusions are compositionally more diverse: the $1 \sigma$ standard deviation in $\mathrm{La} / \mathrm{Yb}$ is 0.98 for inclusions hosted in $\mathrm{An}_{\geq 86}$ plagioclases (relative to 0.53 for Holuhraun). The mean La/ $\mathrm{Yb}$ for inclusions hosted in highAn plagioclases from the $10 \mathrm{ka}$ Grímsvötn tephra series is also much lower than that of its carrier melt $(\mathrm{La} / \mathrm{Yb}=3.6)$. Neave et al. (2015) explained this observation by arguing that high-An macrocrysts from Grímsvötn crystallized from depleted, low-La/ $\mathrm{Yb}$ melts, and were subsequently entrained in a more enriched, high- $\mathrm{La} / \mathrm{Yb}$ melt during convective stirring in magma reservoirs. In contrast, the mean $\mathrm{La} / \mathrm{Yb}$ of the Holuhraun melt inclusions is identical within error to its carrier melt; thus, a complex magmatic plumbing system involving the entrainment of depleted crystal mushes is not required to explain the first-order trace element variability observed in the Holuhraun melt inclusions.

\section{Pressures of melt inclusion crystallization}

Having established that the Holuhraun melt inclusions preserve some record of concurrent mixing and crystallization of diverse primary melts, we next seek to establish where these processes occur within the magmatic system. Pressures of glass and melt inclusion equilibration can be estimated using the position of the olivine-plagioclase-augite-melt (OPAM) thermal minimum as a barometer (e.g., Grove et al. 1993), provided that the melt is saturated in all three phases. Yang et al. (1996) based their parameterisation of olivine-plagioclase-clinopyroxene-saturated experimental melt compositions on a multiple linear regression, where the cation fractions $X_{\mathrm{Mg}}, X_{\mathrm{Ca}}$ and $X_{\mathrm{Al}}$ were expressed as functions of pressure and other melt major element contents.

Crystallization pressures of multiply saturated natural samples can be estimated by visual inspection of projected compositions with respect to the position of the OPAM boundary predicted at a range of pressures (e.g., Yang et al. 1996; Maclennan et al. 2001). Michael and Cornell (1998) rearranged Eq. 2 of Yang et al. (1996) to calculate pressures of crystallization, but this rearrangement is not permitted for relationships derived from multiple linear regression. Kelley and Barton (2008) employed a more complex method: for each sample of interest, they calculated a series of liquid compositions along the olivine-plagioclase-clinopyroxene cotectic at $1 \mathrm{kbar}$ intervals using the Yang et al. (1996) parameterisation, calculated the normative mineral components of these liquids, performed linear regression of pressure against the components for the calculated and original sample compositions, and then calculated a mean estimated equilibration pressure to be used for barometry. The extra steps of ternary projection and linear regression add unnecessary complication and uncertainty to the method. Furthermore, they were not always able to use petrographic and microanalytical measurements to verify that the assumption of multiple saturation in olivine, plagioclase and clinopyroxene was valid. This difficulty may have contributed to the large dispersion in pressure estimates that they found for several Icelandic volcanoes and eruptions. For example, Kelley and Barton (2008) obtained glass crystallization pressures of 1.4-7.7 kbar for Laki, utilising magmatic, phreatomagmatic and rootless cone tephras, glassy lava selvages, and glassy melt inclusion compositions from Thordarson et al. (1996). This is significantly greater pressure range than the $1-2 \pm 1$ kbar obtained by OPAM barometry using only magmatic tephra glasses from the same eruption (Neave et al. 2013). 
Our approach is to use a statistical test to screen melt compositions for three-phase saturation, to have confidence that the OPAM equilibration pressures calculated according to the Yang et al. (1996) parameterization are robust. Measured melt compositions that closely match the $X_{M g}$, $X_{C a}$ and $X_{A l}$ values predicted by equations 1-3 from Yang et al. (1996) calculated at a particular pressure are expected to fall on or near the OPAM boundary-in other words, the melt was saturated in olivine, plagioclase and clinopyroxene at that pressure. This is particularly useful for melt inclusion compositions where the crystallizing assemblage at the time of inclusion trapping can no longer be visually assessed. The first step is to calculate the $\chi^{2}$ misfit for $X_{M g}, X_{C a}$ and $X_{A l}$ between the measured melt compositions and those predicted by the Yang et al. (1996) parameterisation. The Chi square is calculated using the standard expression:

$\chi^{2}=\sum_{i=1}^{3}\left[\frac{X_{i}^{o}-X_{i}^{Y}}{\sigma_{X_{i}}}\right]^{2}$

with $X_{i}^{o}$ the observed cation mole fractions of $\mathrm{Mg}, \mathrm{Ca}$, and Al, $X_{i}^{Y}$ those predicted from the Yang et al. (1996) parameterisation, and $\sigma$ reflecting the analytical uncertainty on glass compositions measured by EPMA, which is taken to be $\pm 5 \%$ reflecting the expected analytical precision for major element oxide components (e.g., Neave et al. 2015). We iteratively solve equations 1-3 from Yang et al. (1996) at 0.01 kbar intervals between -5 and $15 \mathrm{kbar}$, and the minimum $\chi^{2}$ value is found at the best-fitting model pressure. The second step is to estimate the quality of fit between the measured and predicted melt compositions using the $\chi^{2}$ vs. pressure distribution. This provides a significance estimate that we term the probability of fit $P_{\mathrm{F}}$ in the following discussion, which allows us to effectively screen the input melt compositions for three-phase saturation. A crucial point here is that many barometric estimates based on the Yang et al. (1996) parameterisation have not been carefully filtered to ensure that the melts are likely to have been in equilibrium with olivine, plagioclase and clinopyroxene. Using our approach, melts that are far from three-phase saturation, and therefore unsuitable for OPAM barometry, return a low probability of fit and can be excluded from further consideration. The petrography of the Holuhraun samples indicates that the melts were three-phase saturated over the compositional range of the inclusions presented here, with the possible exception of the most primitive inclusions.

\section{Testing the method using experimental data}

Our initial tests on the compositions of experimental charges generated by melting a natural sample of Reykjanes Ridge basalt (Yang et al. 1996) indicate that good $\chi^{2}$ fits can be found, returning probabilities of fit $P_{\mathrm{F}}>0.9$. However, the returned pressures are significant overestimates of the true experimental pressures, with a systematic overestimate of $1.4 \mathrm{kbar}$ and a standard deviation of 0.4 kbar. Similarly, a multiply saturated low- $\mathrm{H}_{2} \mathrm{O}$ MORB composition equilibrated at an experimental pressure of $2.0 \mathrm{kbar}$ (run 127 from Berndt et al. 2005) returned an OPAM pressure of $4.5 \mathrm{kbar}$ and a poor probability of fit $\left(\chi^{2}=31, P_{\mathrm{F}}<0.1\right)$. Experiments on Shatsky Rise samples conducted at pressures of 1-7 kbar (Husen et al. 2016) had generally poor $\chi^{2}$ fits, with only one of 41 experiments returning $P_{\mathrm{F}}>0.9$. For these data, the systematic pressure overestimate was $1.9 \mathrm{kbar}$, and for each defined experimental pressure there is significant variability in the returned OPAM pressure (typically $\sigma=2 \mathrm{kbar}$ ). However, the Shatsky Rise experiments tend to be on more alkaline and more hydrous compositions than either MORB or the Holuhraun melt inclusions and glasses. While the Shatsky Rise samples are classified as tholeiitic basalts (Husen et al. 2016), we note that the OPAM barometer should not be used for transitional or alkali basalt compositions.

Further tests were conducted using an expanded experimental dataset including all the experiments used to calibrate the Yang et al. (1996) parameterisation and a number of more recent studies (Toplis and Carroll 1995; Berndt et al. 2005; Thy et al. 2006; Feig et al. 2006, 2010; Botcharnikov et al. 2008; Whitaker et al. 2007, 2008; Husen et al. 2016), providing a total of 157 experiments on multiply saturated melt compositions (Fig. S10a). Our implementation of the Yang et al. (1996) parameterisation across this dataset yields a systematic pressure overestimate of $1.0 \mathrm{kbar}$, with a substantial random error of $\pm 2.5 \mathrm{kbar}$ (Fig. S10b). When the error in the pressure estimate is plotted as a function of $P_{\mathrm{F}}$ according to the $\chi^{2}$ estimate, a clear pattern emerges. Around $60 \%$ of the experiments provide $P_{\mathrm{F}}<0.8$, where the ability of the Yang et al. (1996) parameterisation to simultaneously fit $X_{M g}, X_{\mathrm{Ca}}$, and $X_{\mathrm{Al}}$ is poor (Fig. S10c). For the $40 \%$ of experiments with $P_{\mathrm{F}}>0.8$, we find a systematic pressure overestimate of $0.34 \mathrm{kbar}$ and random error of $\pm 1.32 \mathrm{kbar}$ (Fig. S10d). The results of these tests indicate that a reasonable strategy is to filter unknown data using the $\chi^{2}$ approach, and then to consider only the pressures that pass the exacting test $P_{\mathrm{F}}>0.8$. This approach enables us to identify and discard melt compositions that are not multiply saturated in olivine, plagioclase and clinopyroxene, or melt inclusion compositions that have been pulled away from the OPAM boundary by significant PEC around the host mineral walls. This minimises the systematic error in the returned pressure estimates. We note that some melt compositions that are three-phase saturated do not pass the $P_{\mathrm{F}}>0.8$ statistical filter, but these false negatives are not important for our purposes. The key objective in setting a high threshold at $P_{\mathrm{F}}>0.8$ is to eliminate false positives, where the melt 
composition is not three-phase saturated and the resultant OPAM pressure is erroneously high.

\section{Application to Holuhraun melt compositions}

We applied our implementation of the Yang et al. (1996) parameterisation to 186 analyses of Holuhraun glass: the ten samples analysed by SIMS in this study, and the compositions used to calculate the OPAM pressures reported by Gudmundsson et al. (2016). Acceptable fits with $P_{\mathrm{F}}>0.8$ were obtained for 134 analyses, returning a mean equilibration pressure of $2.1 \pm 0.7 \mathrm{kbar}$ (Fig. 8a, d). High-MgO glass compositions returned equilibration pressures of 3.0-3.5 kbar; two embayments with acceptable fits $\left(P_{\mathrm{F}}>0.8\right)$ also returned equilibration pressures around $3.0 \mathrm{kbar}$.

Melt inclusion OPAM equilibration pressures were calculated using both raw and PEC-corrected compositions. Of the 105 available raw melt inclusion compositions measured by EPMA, 25 inclusions returned acceptable fits $\left(P_{\mathrm{F}}>0.8\right)$; all of these inclusions were hosted in plagioclase (coloured symbols in Fig. 8b, e). The mean returned equilibration pressure for these 25 inclusions was $2.2 \pm 1.1 \mathrm{kbar}$. There is some indication that the melt inclusions can be subdivided into two populations (Fig. 8e): one of more primitive inclusions $(\mathrm{MgO}>7.5 \mathrm{wt} \%)$ with equilibration pressures of $3.1 \pm 0.7$ $\mathrm{kbar}$ and one of more evolved inclusions $(\mathrm{MgO}<7.5 \mathrm{wt} \%)$ with equilibration pressures of $1.5 \pm 0.9 \mathrm{kbar}$, although there is no clear boundary separating these populations.

Using PEC-corrected melt inclusion compositions, 63 of the 105 melt inclusions returned acceptable fits $\left(P_{\mathrm{F}}>0.8\right.$; coloured symbols in Fig. 8c, f). The mean equilibration pressure is $3.5 \pm 1.7 \mathrm{kbar}$, and there are two distinct peaks in the probability distribution of equilibration pressures, at 3.2 and 7.4 kbar (Fig. 8f). The maximum returned equilibration pressure increases systematically with the extent of PEC experienced by the melt inclusions, but the correlation between equilibration pressure and PEC is not statistically significant $\left(R^{2}=0.24\right.$; Fig. S13). An encouraging feature of the PECcorrected equilibration pressures is that three olivine-hosted inclusions and three clinopyroxene-hosted inclusions also show acceptable fits, and return pressures that lie within the range obtained for PEC-corrected plagioclase-hosted inclusions. The consistency of pressure estimates from inclusions hosted in the three mineral phases involved in the parameterisation (Fig. S14) indicates that the assumption of multiple saturation is likely to be valid for these inclusions.

The highest equilibration pressures $>7 \mathrm{kbar}$ are returned by six PEC-corrected melt inclusions with $\mathrm{MgO}>9.5 \mathrm{wt} \%$ (Fig. 8f; Fig. S15). High-pressure melting experiments on Icelandic basalts suggest that olivine, plagioclase and clinopyroxene can coexist at 6-10 kbar (Fisk et al. 1980), and all six of these inclusions returned $P_{\mathrm{F}}>0.98$. However, we note
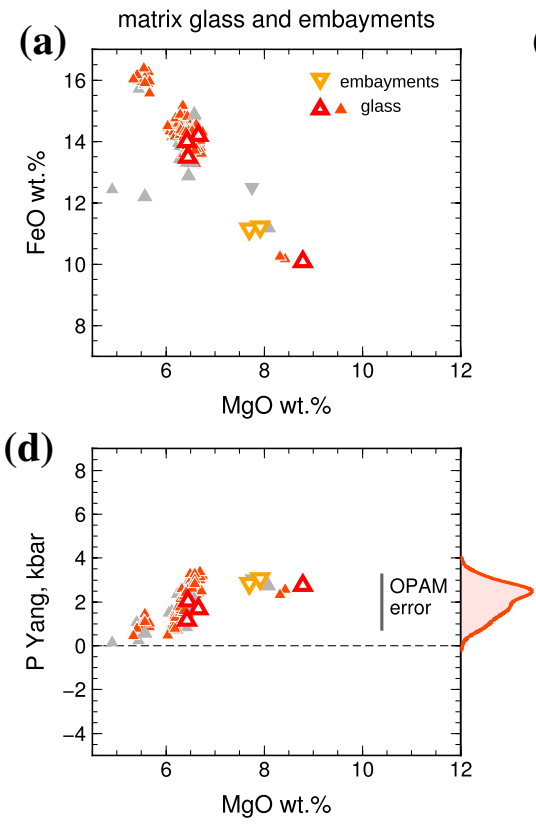
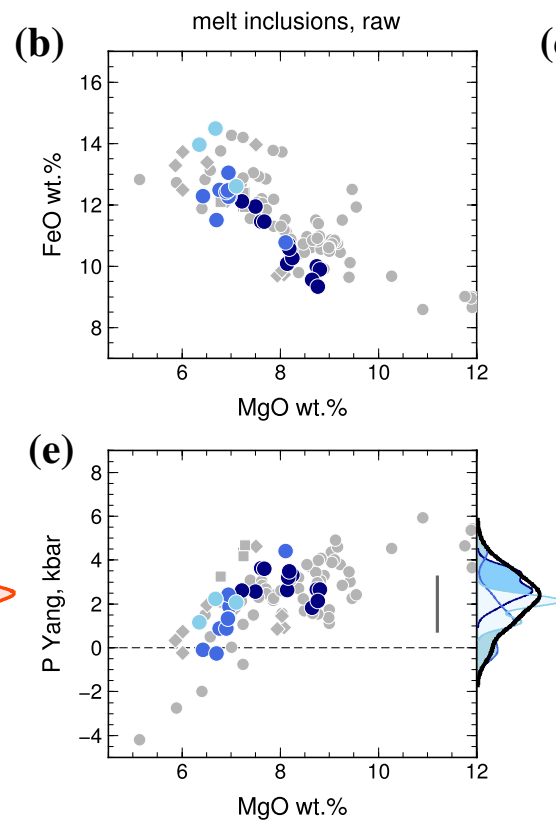
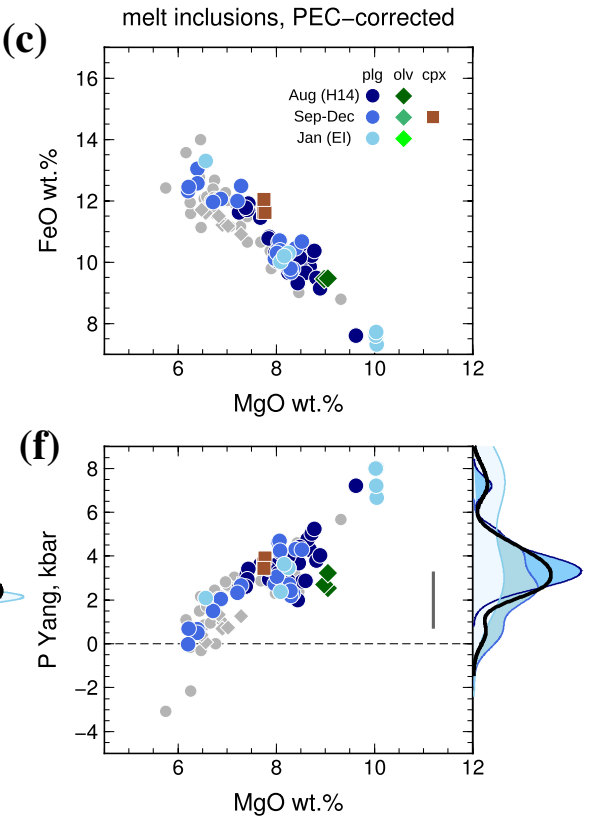

Fig. 8 Application of the Yang et al. (1996) OPAM barometer to Holuhraun erupted products. The upper panels show the compositions of erupted products, and the lower panels show the equilibration pressures returned by OPAM barometry. a, $\mathbf{d}$ Holuhraun matrix glasses and embayments; b, e raw melt inclusion compositions; $\mathbf{c}, \mathbf{f}$ melt inclusions compositions corrected for post-entrapment crystallization. In all plots, coloured symbols with show compositions where the returned probability of fit $P_{\mathrm{F}}$ is greater than 0.8 , and grey symbols show compositions where $P_{\mathrm{F}}<0.8$. Kernel density estimates to the right of plots $\mathbf{d}-\mathbf{f}$ show the relative probability of equilibration pressures for compositions with $P_{\mathrm{F}}>0.8$. The blue kernel density curves correspond to plagioclase-hosted inclusions collected on different dates; the black curve shows all melt inclusions with $P_{\mathrm{F}}>0.8$ 
that these inclusions have PEC corrections of $12-16 \%$ and their PEC-corrected compositions do not precisely match published compositions for Bárðarbunga glasses (Fig. 3). The apparent three-phase saturation of these inclusions may therefore be an artefact of the PEC correction, and the high equilibration pressures are treated with caution.

The remaining 57 inclusions have shallower trapping pressures with a peak in the probability distribution at 3.2 kbar. Kernel density plots subdivided by eruption date indicate that melt inclusion trapping pressures may have varied over time (Fig. 8f). Inclusions from 31 August 2014 (sample $\mathrm{H} 14$ ) have a peak in the probability distribution at $3.4 \mathrm{kbar}$ with a subsidiary shoulder at $5.0 \mathrm{kbar}$; no inclusions from this sample return equilibration pressures shallower than 2.0 kbar. In contrast, inclusions in samples collected between September and November 2014 have peaks in the probability distribution at $0.7,2.5$, and $4.2 \mathrm{kbar}$. These differences are just resolvable within the \pm 1.32 kbar uncertainty of the OPAM barometer. Finally, inclusions from 22 January 2015 (sample EI) return equilibration pressures around 3.0 and $7.5 \mathrm{kbar}$, but the probability distribution for this sample is not well defined due to the small number of samples $(n=8)$.

Equilibration pressures of 3.4-5.0 kbar for inclusions from sample $\mathrm{H} 14$ are consistent with trapping pressures of $4.1 \mathrm{kbar}$ recorded by high-density $\mathrm{CO}_{2}$ fluid inclusions in macrocrysts from the same sample (Bali et al. 2018). Similarly, $\mathrm{CO}_{2}$-rich fluid inclusions in macrocrysts erupted from September 2014 onwards record trapping pressures of $2.5 \mathrm{kbar}$ or less (Bali et al. 2018), consistent with the shallower melt equilibration pressures in these later samples. Although the difference in mean melt inclusion equilibration pressures between sample H14 and later samples is smaller than the estimated uncertainty on our implementation of the Yang et al. (1996) barometer, the distribution of equilibration pressures and fluid inclusion trapping pressures permits the suggestion that the first-erupted magmas entrained and transported plagioclase macrocrysts from deeper in the Holuhraun magmatic system than later-erupted products. Melt inclusions trapped at the very base of the Holuhraun magmatic system at $>7 \mathrm{kbar}$ are sampled infrequently and have been recovered only in macrocrysts from the start and end of the eruption. However, the small number of inclusions $(n=6)$ means that it not possible to speculate whether this distribution is reliably indicative of changes in the magma supply over the course of the eruption.

A limitation of the Yang et al. (1996) parameterisation is that it does not take the oxidation state or $\mathrm{Cr}$ content of the melt into account. We therefore re-calculated the Holuhraun glass and melt inclusion equilibration pressures using a reparameterisation of the OPAM barometer that takes into account melt $\mathrm{Fe}^{3+}$ and $\mathrm{Cr}$ contents, and is calibrated against experimental studies that were not included in our implementation (Voigt et al. 2017, and references therein). The pressures obtained from the Voigt et al. (2017) parameterisation agree with our implementation to within $0.1 \mathrm{kbar}$. This agreement is better than the calibration uncertainty associated with either barometer, which lends confidence to our returned OPAM equilibration pressures of 2.0-3.0 kbar for Holuhraun glasses and later-erupted melt inclusions. Furthermore, both OPAM models return equilibration pressures that are within error of the 2.5-3.5 kbar pressures returned by clinopyroxene-liquid barometry (Hartley et al. 2017).

Our returned OPAM pressures are shallower than the 3.6-5.0 kbar reported by Gudmundsson et al. (2016). These authors calculated OPAM equilibration pressures for Holuhraun glasses using the Kelley and Barton (2008) implementation (hereafter KB08). We tested KB08 using the same experimental data used to calibrate our implementation of the Yang et al. (1996) OPAM parameterisation. Pressures returned by the KB08 approach overestimated the true experimental pressures by an average $0.9 \mathrm{kbar}$ (Figs. S11, S12). Taking this overestimate into account, the OPAM pressures reported by Gudmundsson et al. (2016) are reduced to $2.7-4.1 \mathrm{kbar}$. The shallowest pressures in this range are therefore within error of our calculated glass equilibration pressures. The remaining scatter in the glass pressures reported by Gudmundsson et al. (2016) may be due to the fact that 52 of the 184 Holuhraun glass compositions returned $P_{\mathrm{F}}<0.8$ indicating that they are unsuitable for OPAM barometry, yet these compositions are not screened out when the KB08 method is adopted.

Having established the pressures of melt mixing, crystallization, and melt inclusion trapping in the Holuhraun magmatic system, we next consider the timescales over which these processes occurred.

\section{$\mathrm{H}_{2} \mathrm{O}, \mathrm{Ce}$, and the diffusive re-equilibration of $\mathrm{H}_{2} \mathrm{O}$ : constraints on crystal residence timescales}

Recent studies of both natural and experimental samples have shown that at magmatic temperatures, the $\mathrm{H}_{2} \mathrm{O}$ contents of crystal-hosted melt inclusions may be modified by several weight percent on timescales of hours to days by diffusive re-equilibration of $\mathrm{H}^{+}$between the melt inclusion and its external environment (e.g., Portnyagin et al. 2008; Gaetani et al. 2012; Bucholz et al. 2013; Hartley et al. 2015). Magmatic water contents at the time of melt inclusion trapping can be estimated using $\mathrm{Ce}$ as a proxy for $\mathrm{H}_{2} \mathrm{O}$, if the undegassed $\mathrm{H}_{2} \mathrm{O} / \mathrm{Ce}$ of the primary melt is known. Determining a primary $\mathrm{H}_{2} \mathrm{O} / \mathrm{Ce}$ value for Holuhraun is challenging, since no melt inclusions or glasses in our study preserve $\mathrm{H}_{2} \mathrm{O}$ contents that can be unambiguously recognised as unmodified (Fig. 9a). The vesicular tephra glasses contain on average 0.1 wt $\% \mathrm{H}_{2} \mathrm{O}$ and are considered to be degassed. However, the $\mathrm{H}_{2} \mathrm{O}$ contents of the non-vesicular glasses and embayments are positively correlated with $\mathrm{K}_{2} \mathrm{O}$ and $\mathrm{Ce}$ and negatively 


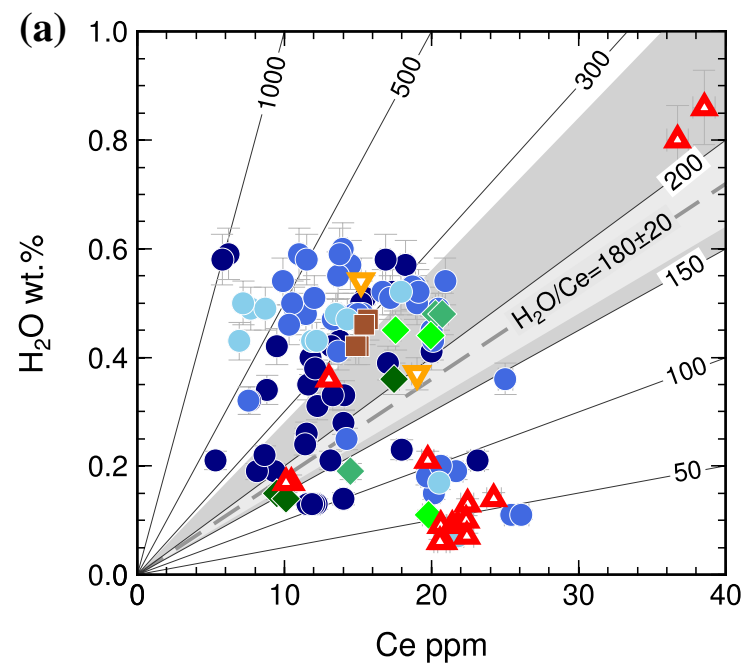

Fig. 9 a $\mathrm{H}_{2} \mathrm{O}$ vs. Ce for melt inclusions and glasses from Holuhraun, using the same symbols as Fig. 3. Lines show contours of constant $\mathrm{H}_{2} \mathrm{O} / \mathrm{Ce}$. The light grey-shaded area shows the unmodified $\mathrm{H}_{2} \mathrm{O}$ / $\mathrm{Ce}=180 \pm 20$ determined for Iceland's Eastern Volcanic Zone (Hartley et al. 2015); the dark grey-shaded area indicates the expected range in $\mathrm{H}_{2} \mathrm{O} / \mathrm{Ce}$ for undegassed MORB glasses, $150<\mathrm{H}_{2} \mathrm{O} / \mathrm{Ce}<280$

correlated with $\mathrm{MgO}$, as expected for a relationship governed by fractional crystallization rather than degassing. If these samples are assumed to be representative of the undegassed carrier melt, then $\mathrm{H}_{2} \mathrm{O} / \mathrm{Ce}$ for Holuhraun can be estimated at $253 \pm 64(1 \sigma)$ (Fig. 9a). This is higher than the primary $\mathrm{H}_{2} \mathrm{O} / \mathrm{Ce}$ value of $180 \pm 20$ previously estimated for the southern sector of the EVZ (Hartley et al. 2015), which may reflect regional heterogeneity in the Icelandic mantle source.

Melt inclusions with the highest $\mathrm{H}_{2} \mathrm{O} / \mathrm{Ce}$ values are hosted in the most anorthitic plagioclases (Fig. 9b). The mean $\mathrm{H}_{2} \mathrm{O} / \mathrm{Ce}$ decreases steadily for inclusions hosted in $\mathrm{An}_{87}-\mathrm{An}_{78}$ plagioclases, but rises slightly for inclusions hosted in $\mathrm{An}_{77}-\mathrm{An}_{70}$ plagioclases (Fig. 9b). We find no relationship between $\mathrm{H}_{2} \mathrm{O} / \mathrm{Ce}$ and $\mathrm{La} / \mathrm{Yb}$. This contrasts with olivine-hosted melt inclusions from Laki and Skuggafjöll, where variation in $\mathrm{H}_{2} \mathrm{O} / \mathrm{Ce}$ was controlled principally by primary melt variability: the most depleted inclusions experienced the greatest extent of diffusive hydration and had the highest $\mathrm{H}_{2} \mathrm{O} / \mathrm{Ce}$ values (Hartley et al. 2015). In contrast, parental melts at Holuhraun are likely to have been more homogeneous, such that melt inclusion Ce contents at a given $\mathrm{La} / \mathrm{Yb}$ are controlled by fractional crystallization rather than by mantle-derived variability.

The variable $\mathrm{H}_{2} \mathrm{O}$ contents and $\mathrm{H}_{2} \mathrm{O} / \mathrm{Ce}$ values of Holuhraun melt inclusions suggest complex magmatic histories. High $\mathrm{H}_{2} \mathrm{O} / \mathrm{Ce}$ in some inclusions (Fig. 9) may be taken as an indication of equilibration with a more hydrous carrier melt prior to eruption. In contrast, inclusions with low $\mathrm{H}_{2} \mathrm{O}$ contents and low $\mathrm{H}_{2} \mathrm{O} / \mathrm{Ce}$ may either have trapped a partially

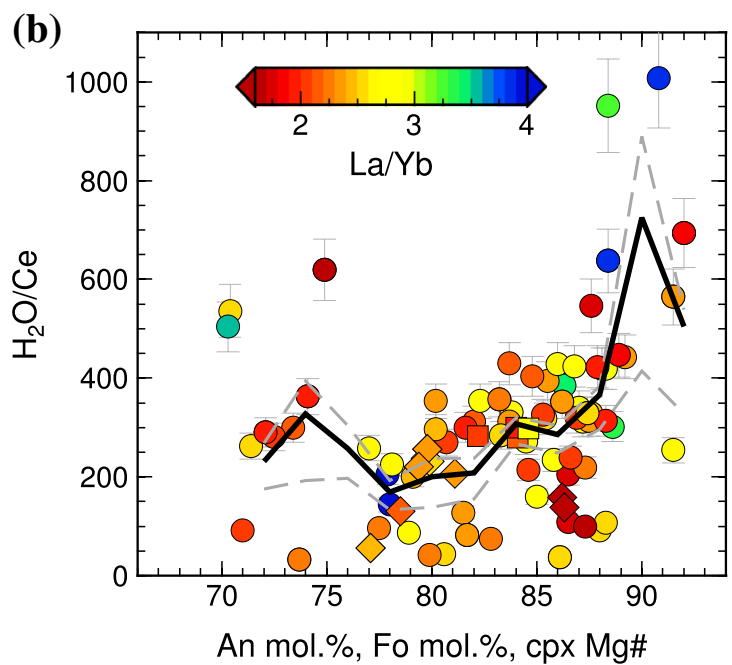

(Michael et al. 1995). b $\mathrm{H}_{2} \mathrm{O} / \mathrm{Ce}$ vs. host macrocryst composition, coloured by $\mathrm{La} / \mathrm{Yb}$. The black solid line shows the running average $\mathrm{H}_{2} \mathrm{O} / \mathrm{Ce}$ for plagioclase-hosted melt inclusions (circles) calculated using a boxcar filter with bandwidth of $2 \mathrm{~mol} \% \mathrm{An}$; dashed grey lines show the standard error of estimate for the filtered data

degassed melt or experienced diffusive re-equilibration with a degassed carrier melt. It is possible that some of the Holuhraun melt inclusions preserve the magmatic $\mathrm{H}_{2} \mathrm{O}$ content at the time of inclusion trapping. However, by assuming that all the Holuhraun melt inclusions were trapped with initially primary $\mathrm{H}_{2} \mathrm{O} / \mathrm{Ce}$ and that any modification of $\mathrm{H}_{2} \mathrm{O} / \mathrm{Ce}$ was caused by post-entrapment $\mathrm{H}^{+}$diffusion, it is possible to place minimum constraints on the residence timescales of host macrocrysts in different magmatic environments.

To estimate timescales of diffusive re-equilibration between melt inclusions and their external environment, we use a modified version of the model presented by Bucholz et al. (2013) to calculate an analytical solution for symmetric $\mathrm{H}^{+}$diffusion through spherical crystals hosting spherical melt inclusions at their centres (Qin et al. 1992). Melt inclusion and host crystal dimensions were measured using a binocular microscope; the observed crystal shapes indicate that host crystals can be assumed to be whole crystals unaffected by syn-eruptive fragmentation. To model $\mathrm{H}^{+}$diffusion in olivine, we used a partition coefficient $\mathrm{K}_{\mathrm{H}_{2} \mathrm{O}}^{\text {olvelt }}=0.0007$ (Le Voyer et al. 2014) and diffusion coefficient $D_{H^{+}[001]}^{\text {olv }}=10^{-1.4} \exp [-(258 / R T)] \mathrm{m}^{2} / \mathrm{s}$ (Demouchy and Mackwell 2006). For plagioclase, we used a partition coefficient $K_{\mathrm{H}_{2} \mathrm{O}}^{\mathrm{plg} \text {-melt }}=0.01$ (Hamada et al. 2011). The diffusivity of $\mathrm{H}^{+}$in high-anorthite plagioclase is approximately one order of magnitude slower than for olivine (Johnson and Rossman 2013), but has not been quantified experimentally at temperatures $>1000{ }^{\circ} \mathrm{C}$. We therefore estimated an 
appropriate diffusion coefficient $D_{\mathrm{H}^{+}}^{\mathrm{plg}}$ by extrapolating the model of Johnson and Rossman (2013) to higher temperatures.

At magmatic conditions of $3 \pm 1 \mathrm{kbar}$ and $1170^{\circ} \mathrm{C}$, PECcorrected Holuhraun melt inclusions with (1) depleted compositions with $\mathrm{La} / \mathrm{Yb}<1.5$ and initial $\mathrm{H}_{2} \mathrm{O}$ contents predicted assuming a primary $\mathrm{H}_{2} \mathrm{O} / \mathrm{Ce}$ of 253 have water activities $\left(a \mathrm{H}_{2} \mathrm{O}\right)$ of $\sim 0.020-0.053$, and (2) enriched compositions with $\mathrm{La} / \mathrm{Yb}>3.5$ have $a \mathrm{H}_{2} \mathrm{O}$ of $\sim 0.025-0.145$ (Burnham 1979). Taking the mean Ce content of the vesicular tephra glass $(21.7 \pm 1.3 \mathrm{ppm})$ and $\mathrm{H}_{2} \mathrm{O} / \mathrm{Ce}=253 \pm 64$, the undegassed Holuhraun carrier melt is predicted to contain $0.55 \pm 0.17 \mathrm{wt} \% \mathrm{H}_{2} \mathrm{O}$, with a corresponding $a \mathrm{H}_{2} \mathrm{O}$ of $0.42_{-0.19}^{+0.24}$. Entrainment of melt inclusion-bearing macrocrysts into a carrier melt of this composition thus results in an $a \mathrm{H}_{2} \mathrm{O}$ gradient sufficient to facilitate diffusive over-hydration of the melt inclusions.

Eight melt inclusions have measured $\mathrm{H}_{2} \mathrm{O}>0.55 \mathrm{wt} \%$, with the highest measured $\mathrm{H}_{2} \mathrm{O}$ content being $0.6 \mathrm{wt} \%$. In addition, 27 melt inclusions have measured $\mathrm{H}_{2} \mathrm{O} / \mathrm{Ce}>317$,

(a) hydration

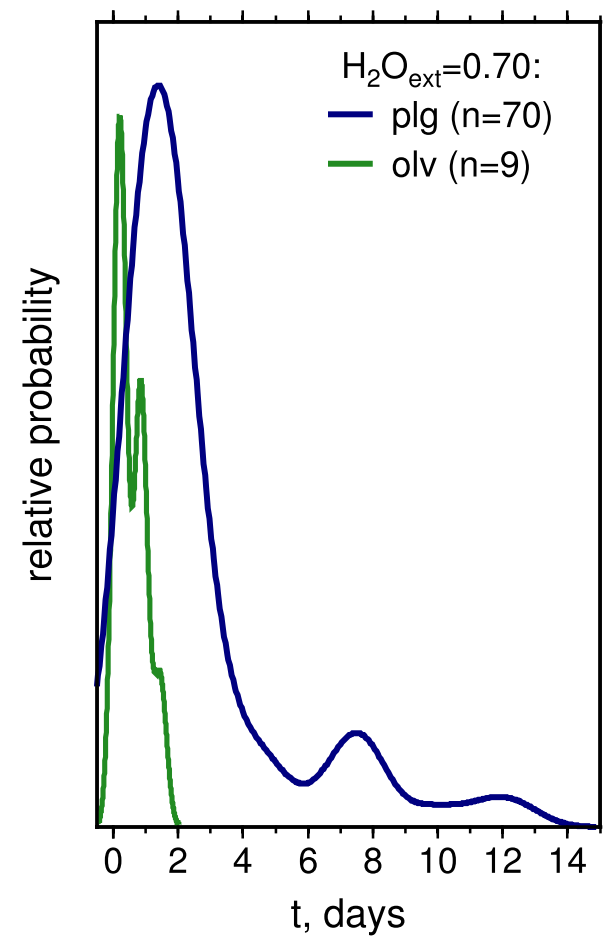

Fig. 10 Kernel density estimates of calculated diffusive re-equilibration timescales for plagioclase-hosted melt inclusions. a Diffusive over-hydration of melt inclusions. Calculations assume that melt inclusions with initial primary $\mathrm{H}_{2} \mathrm{O} / \mathrm{Ce}=253$ equilibrated with a melt composition identical to the carrier melt at $1170{ }^{\circ} \mathrm{C}$. Timescales were modelled assuming an $\mathrm{H}_{2} \mathrm{O}$ content of $0.7 \mathrm{wt} \%$ for the external carrier melt, predicted using the measured Ce content of the most i.e., higher $\mathrm{H}_{2} \mathrm{O}$ contents than can be explained by primary melt heterogeneity alone. These values suggest that some inclusions were stored for part of their history in a melt that was more hydrous than the Holuhraun carrier melt, and gained $\mathrm{H}_{2} \mathrm{O}$ by diffusive hydration. The most evolved melt inclusion, with $\mathrm{Ce}=27.6 \mathrm{ppm}$, can be used to estimate a maximum $\mathrm{H}_{2} \mathrm{O}$ content of $0.70 \pm 0.17 \mathrm{wt} \%$ for this evolved carrier melt. We therefore calculated diffusive over-hydration timescales for each melt inclusion, assuming an external melt $\mathrm{H}_{2} \mathrm{O}$ content of $0.70 \mathrm{wt} \%$ and using the measured $\mathrm{Ce}$ content to calculate the initial $\mathrm{H}_{2} \mathrm{O}$ content, where primary $\mathrm{H}_{2} \mathrm{O} / \mathrm{Ce}=253$. Calculations were performed at $3 \mathrm{kbar}$ and $1170{ }^{\circ} \mathrm{C}$, and were terminated when the melt inclusions reached equilibrium with the external melt. The calculated re-equilibration timescales for olivine- and plagioclasehosted inclusions in a carrier melt containing $0.70 \mathrm{wt} \% \mathrm{H}_{2} \mathrm{O}$ ranged from 0.4 to 12.5 days, with a peak in the probability distribution at 1.4 days (Fig. 10a). These calculations assume that all the melt inclusions were stored in, and completely re-equilibrated with, a hydrous external melt at some point in their history. While it is not possible to constrain

\section{(b) dehydration}

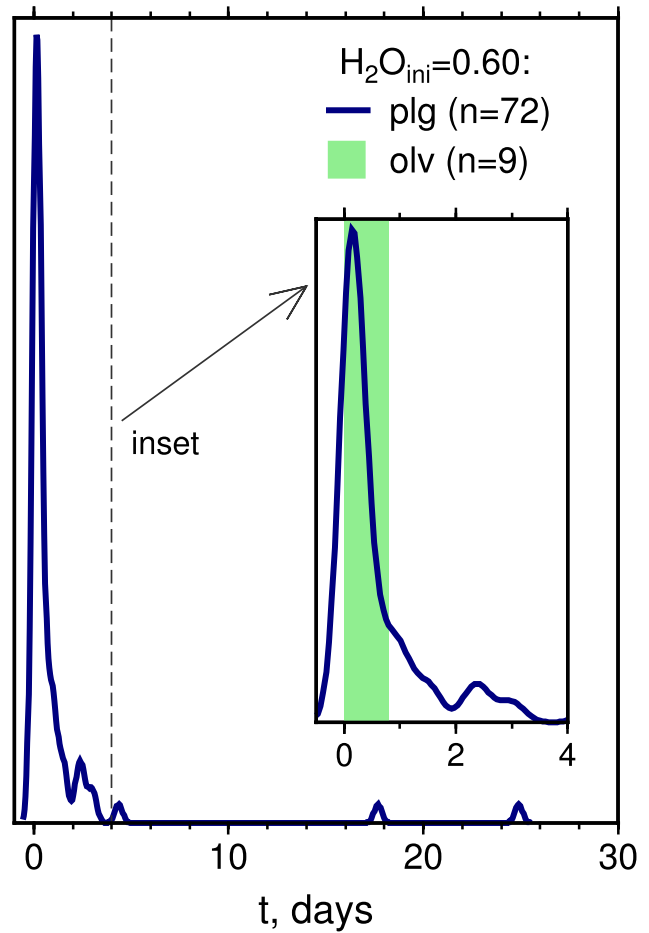

enriched melt inclusion. b Diffusive dehydration of melt inclusions. Calculations assume that melt inclusions initially in equilibrium with an undegassed carrier melt partially re-equilibrated with a degassed carrier liquid containing $0.08 \mathrm{wt} \% \mathrm{H}_{2} \mathrm{O}$ at $1150{ }^{\circ} \mathrm{C}$. On each plot, the vertical bars show the range of diffusion timescales obtained for olivine-hosted melt inclusions calculated under the same conditions 
whether or not individual inclusions experienced these magmatic conditions prior to eruption, the calculated timescales provide some indication of minimum crystal residence durations within the Holuhraun magmatic system.

The two longest melt inclusion hydration timescales of 11-12 days are comparable with the 14 days of pre-eruptive seismicity on the Bárðarbunga volcanic system (Sigmundsson et al. 2015). The melt transport rate is likely to be faster than this once an open dyke pathway exists between Bárðarbunga and the eruption site, and this may be reflected in the more typical minimum crystal residence timescales of 1-3 days. However, there is no difference in the distribution of minimum crystal residence timescales between sample H14 from 31 August 2014 and samples collected later in the eruption. This suggests that some crystals may have been entrained into the Holuhraun melt only a short time before eruption, and highlights a degree of chemical disequilibrium between the carrier melt and the macrocrysts it carried to the surface. Erupted products from the Bárðarbunga volcanic system commonly carry large plagioclase macrocrysts that exhibit chemical and isotopic disequilibrium with their carrier melt (Hansen and Grönvold 2000; Halldórsson et al. 2008). While it is expected that some melt inclusion-bearing plagioclases did crystallize directly from parental melts of the Holuhraun magma, it is not possible to definitively identify these macrocrysts from our current data.

For melt inclusions with $\mathrm{H}_{2} \mathrm{O} / \mathrm{Ce} \ll 253$, we calculated timescales of diffusive $\mathrm{H}^{+}$loss assuming that these inclusions were transported in a degassed carrier melt containing $0.08 \mathrm{wt} \% \mathrm{H}_{2} \mathrm{O}$ (the measured $\mathrm{H}_{2} \mathrm{O}$ content of the most degassed vesicular tephra glasses) during ascent and eruption. Diffusive dehydration most probably occurred during subsurface magma transport, since post-eruptive re-equilibration of melt inclusions in rapidly quenched tephra samples can be assumed to be negligible. Dehydration modelling was conducted assuming that the inclusions were initially in equilibrium with a final carrier melt containing $0.60 \mathrm{wt} \%$ $\mathrm{H}_{2} \mathrm{O}$. This melt $\mathrm{H}_{2} \mathrm{O}$ content is selected because (a) it is within the range of predicted carrier melt $\mathrm{H}_{2} \mathrm{O}$ contents for Holuhraun, and (b) it is the measured $\mathrm{H}_{2} \mathrm{O}$ content of the most hydrous melt inclusion. Dehydration calculations were performed at atmospheric pressure and $1150{ }^{\circ} \mathrm{C}$, and were terminated when melt inclusions reached their measured $\mathrm{H}_{2} \mathrm{O}$ contents. Petrologically, this means that the melt inclusions ascended to the surface fast enough to prevent complete diffusive dehydration, and permits some inclusions to retain high $\mathrm{H}_{2} \mathrm{O}$ contents and high $\mathrm{H}_{2} \mathrm{O} / \mathrm{Ce}$ acquired during a past episode of diffusive hydration.

Olivine-hosted inclusions with measured $\mathrm{H}_{2} \mathrm{O} / \mathrm{Ce}<253$ would have required 0.02-0.8 days to reach their measured $\mathrm{H}_{2} \mathrm{O}$ contents by partial re-equilibration with a degassed carrier melt (Fig. 10b). Dehydrated plagioclase-hosted inclusions would have taken between 0.02 and 25 days to reach their measured $\mathrm{H}_{2} \mathrm{O}$ contents, with the peak in the probability distribution being 0.14 days (Fig. 10b). The two inclusions with calculated dehydration timescales $>5$ days have measured $\mathrm{H}_{2} \mathrm{O}$ contents of 0.07 and $0.08 \mathrm{wt} \%$. Both inclusions are from sample EI, which consists of scoria clasts collected from the side of the main eruptive vent. It is possible that these inclusions were thermally insulated and underwent diffusive dehydration over several days. However, other inclusions from the same sample preserve $\mathrm{H}_{2} \mathrm{O}$ contents up to $0.50 \mathrm{wt} \%$ and $\mathrm{H}_{2} \mathrm{O} / \mathrm{Ce}>253$. We therefore suggest that the low- $\mathrm{H}_{2} \mathrm{O}$ inclusions formed at a late stage of crystallization and trapped an already degassed melt, which is consistent with these inclusions being located close to the rims of their host macrocrysts.

Given the uncertainty regarding the $\mathrm{H}_{2} \mathrm{O}$ content of the carrier melt(s) in which macrocrysts and microphenocrysts resided within the Holuhraun magmatic system, and the rapidity of $\mathrm{H}^{+}$diffusion in both olivine and plagioclase, diffusive re-equilibration of $\mathrm{H}^{+}$in melt inclusions provides only a minimum estimate of crystal residence timescales in the Holuhraun carrier melt. At present, it is not possible to constrain maximum crystal residence timescales in the Holuhraun magma, nor durations of crystal storage in magma chambers or crystal mush horizons prior to entrainment. Future studies will therefore focus on major and trace element diffusion chronometry in olivine and plagioclase to establish the provenance and magmatic histories of these crystals.

It is possible to use our calculated dehydration timescales to estimate the rates at which crystals moved to the surface after their carrier melt crossed the pressure of water saturation. Closed-system degassing has been argued to be significant in basaltic magmatic systems (e.g., Allard et al. 2005; Lloyd et al. 2014; Ferguson et al. 2016). Volatile saturation models (Newman and Lowenstern 2002; Witham et al. 2012) predict that the Holuhraun carrier liquid becomes water-saturated at pressures between $\sim 1.0$ and 0.4 kbar during closed-system degassing, with the variability arising from the choice of initial magmatic $\mathrm{CO}_{2}$ content and hence the mass percent of pre-existing exsolved vapour present. Assuming an initial volatile budget of $3000 \mathrm{ppm} \mathrm{CO}$ and $0.6 \mathrm{wt} \% \mathrm{H}_{2} \mathrm{O}$, the Holuhraun melt will begin to degas $\mathrm{H}_{2} \mathrm{O}$ at $1.0 \mathrm{kbar}$, but significant $\mathrm{H}_{2} \mathrm{O}$ loss only occurs at pressures below $\sim 0.4$ kbar. Combining these pressure estimates with diffusive dehydration timescales of 0.02-25 days and an average crustal density of $2.86 \times 10^{3} \mathrm{~kg} \mathrm{~m}^{-3}$ allows us to calculate indicative magma ascent rates for the upper part of the conduit of between 0.001 and $1.7 \mathrm{~m} \mathrm{~s}^{-1}$, with the most probable dehydration timescales corresponding to ascent rates of $0.12-0.29 \mathrm{~m} \mathrm{~s}^{-1}$. These estimates represent minimum ascent rates, since we do not take into account the likelihood of $\mathrm{H}_{2} \mathrm{O}$ supersaturation and disequilibrium degassing 
during ascent. Our estimates are significantly slower than the magma transfer rate of $0.75 \mathrm{~m} \mathrm{~s}^{-1}$ obtained from radioactive disequilibria in Holuhraun gas phase samples (Gauthier et al. 2016). However, the rate of $0.75 \mathrm{~m} \mathrm{~s}^{-1}$ is based on the outgassing of volatile radionuclides upon early $\mathrm{CO}_{2}$ loss at depth within the magmatic system, and thus represents a different stage of magma ascent than has been considered in our calculation. Our calculated ascent rates are slower than the $0.05-0.45 \mathrm{MPa} \mathrm{s}^{-1}$ $\left(\sim 1.7-15 \mathrm{~m} \mathrm{~s}^{-1}\right)$ obtained for various eruptions at Kilauea, Hawaii (Ferguson et al. 2016), but our higher estimates are comparable with ascent rates of $\sim 0.2-2.0 \mathrm{~m} \mathrm{~s}^{-1}$ modelled for Stromboli (e.g., Pichavant et al. 2013).

\section{Comparison of petrological and geophysical datasets}

Melt inclusion and carrier melt equilibration and trapping depths are compared with the depths of pre-eruptive seismicity in Fig. 11a. Equilibration depths for the carrier melt are comparable with the 3-9 $\mathrm{km}$ depth range of the preeruptive seismicity (Sigmundsson et al. 2015). The most probable melt equilibration pressure, $2.1 \pm 0.7 \mathrm{kbar}$, corresponds to a depth of $7.5 \pm 2.5 \mathrm{~km}$ and is in good agreement with the most common earthquake hypocentral depth of $6 \pm 1 \mathrm{~km}$ (Ágústsdóttir et al. 2016). Taken at face value, melt barometry is thus consistent with models put forward

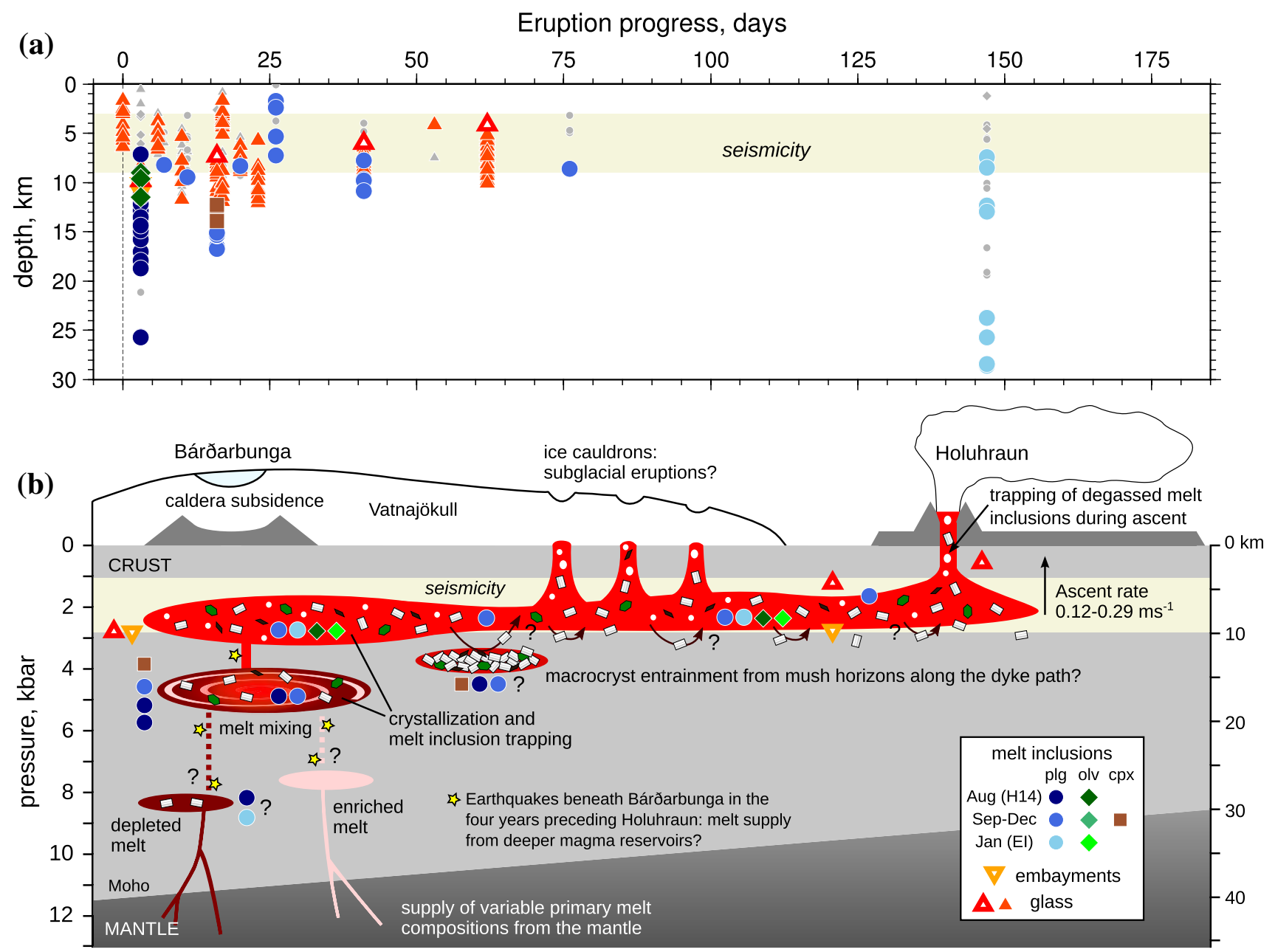

Fig. 11 a Comparison of melt inclusion and glass OPAM equilibration depths with the depth of laterally propagating seismicity between Bárðarbunga and the eruption site. The coloured symbols show melt compositions where the returned probability of fit $P_{\mathrm{F}}$ to the Yang et al. (1996) OPAM barometer is greater than 0.8, and grey symbols show compositions where $P_{\mathrm{F}}<0.8$. OPAM equilibration pressures were converted to depths assuming a crustal density of $2.86 \times 10^{3} \mathrm{~kg}$ $\mathrm{m}^{-3}$. b Schematic illustration showing how the Holuhraun magma may have been assembled and transported. Caldera subsidence at
Bárðarbunga is likely related to magma draining from a shallow (2-3 kbar) magma reservoir into a lateral dyke. Three ice cauldrons along the dyke path most probably indicate the sites of small subglacial eruptions (Reynolds et al. 2017). Coloured symbols indicate the possible origins of melt inclusion- and embayment-bearing macrocrysts at the relevant pressures of crystallization. Macrocrysts may have been transported from magma reservoirs beneath Bárðarbunga, or entrained from mush horizons along the dyke path 
involving lateral magma transport from Bárðarbunga volcano to the eruption site in a shallow- to mid-crustal dyke (Gudmundsson et al. 2016).

Some PEC-corrected melt inclusion equilibration depths cluster around $10 \mathrm{~km}$ (Fig. 8f), towards the base of the inferred lateral intrusion, but many equilibrate somewhat deeper (Fig. 11a). There appears to be a progressive shallowing of melt inclusion equilibration pressures over the course of the eruption (Figs. 8, 11a), which could be indicative of differences in the efficiency of crystal entrainment during the initial stages of melt ascent. Dyke propagation may have mobilised crystals from mush horizons beneath Bárðarbunga and/or from near the base of the magma intrusion at any point along the dyke path. As the eruption progressed and an open magma pathway was established, crystal entrainment may have been inhibited by viscous drag at the base of the dyke.

Melt inclusions from samples collected during the first 20 days of the eruption have equilibration depths ranging from 7.1 to $25.7 \mathrm{~km}$, with most inclusions equilibrating significantly deeper than all but the very deepest earthquakes associated with dyke propagation (Fig. 11a). Regional geodetic modelling of caldera subsidence at Bárðarbunga implies a deflating source at 8-12 km (Gudmundsson et al. 2016) which provides an independent estimate of the likely depth of magma storage beneath Bárðarbunga. While the most probable melt inclusion equilibration depth of $11.4 \mathrm{~km}$ falls towards the lower end of this range, exactly half of the melt inclusions return equilibration depths in excess of $12 \mathrm{~km}$. This implies that their host macrocrysts crystallized and trapped their inclusions at deeper levels in the crust, and were transported into the Bárðarbunga magma reservoir prior to the onset of seismicity on 16 August 2014. The occurrence of deep (12-25 km) earthquakes in the area east of Bárðarbunga over the 4 years preceding the Holuhraun eruption (Vogfjörð et al. 2015; Hudson et al. 2017) could be consistent with magma supply from depth to a reservoir 8-12 km beneath Bárðarbunga (Fig. 11b). Intriguingly, our maximum equilibration depths of 23.7-28.6 km match very closely the greatest depths of seismicity, which lends some confidence to these results.

Using geochemical and petrological data to reconstruct the magmatic systems that feed fissure eruptions is subject to a number of limitations. For example, while melt barometers such as that of Yang et al. (1996) are able to resolve depths of melt storage and crystallization within the uncertainty of the chosen barometer, they cannot resolve melt transport pathways in the lateral (i.e., horizontal) dimension. In the absence of geophysical and geodetic constraints on the nature of melt supply and transport, the simplest interpretation of our petrological and geochemical data would be that the Holuhraun eruption was fed via a vertically stacked series of interconnected magma reservoirs. Furthermore, while our data are consistent with the Holuhraun carrier melt being sourced beneath Bárðarbunga, we cannot definitively identify the position along the magma transport pathway at which melt inclusion-bearing macrocrysts were entrained. Our calculated diffusive hydration timescales for Holuhraun melt inclusions provide robust minimum residence timescales for host macrocrysts in the Holuhraun carrier melt on the order of 1-12 days. Diffusion chronometry in zoned melt inclusion-bearing macrocrysts may provide further constraints on whether macrocryst residence timescales in the carrier melt coincide with the onset of seismicity and lateral melt transport through the volcanic system, or whether these macrocrysts were entrained close to the eruptive vents with correspondingly short residence timescales.

\section{Conclusions}

The 2014-2015 Holuhraun eruption was one of the bestmonitored basaltic fissure eruptions ever to have occurred. We have used major, light lithophile, trace and rare-earth element data from crystal-hosted melt inclusions, embayments, and matrix glasses to investigate melt mixing, crystallization timescales, and transport processes in the Holuhraun magmatic system. Holuhraun melt inclusion and glass compositions are similar to Holocene erupted products from the Bárðarbunga volcanic system, and near-identical to the products of two older eruptions at Holuhraun. The range in major element compositions of Holuhraun melt inclusions, corrected for post-entrapment crystallization, resembles a liquid line of descent, although fractional crystallization alone is unable to explain the observed compositional diversity. Olivine-plagioclase-augite-melt barometry returns melt inclusion equilibration pressures between 0.5 and $8.0 \mathrm{kbar}$. A significant peak in the probability distribution at $3.2 \mathrm{kbar}$ indicates the most likely pressure of melt storage, crystallization, and inclusion trapping. The mean matrix glass equilibration pressure of $2.1 \pm 0.7 \mathrm{kbar}$ is in close agreement with pressure estimates derived from clinopyroxene-liquid barometry, and within error of the depths of earthquakes between Bárðarbunga central volcano and the Holuhraun eruption site.

The diversity in incompatible trace element ratios such as $\mathrm{La} / \mathrm{Yb}$ in Holuhraun melt inclusions is best explained by the concurrent mixing and crystallization of diverse primary melts. The absolute variability in melt inclusion compositions appears to be more restricted than has been inferred for other Icelandic eruptions, although it is possible that the Holuhraun melt inclusion record does not capture the earliest stages of melt mixing and crystallization. Diffusion chronometry based on $\mathrm{H}^{+}$re-equilibration between melt inclusions and a more hydrous carrier melt indicates minimum residence times of 1-12 days for melt inclusion-bearing 
macrocrysts in the Holuhraun carrier melt. Similarly, diffusive dehydration of $\mathrm{H}_{2} \mathrm{O}$-rich melt inclusions stored in a less hydrous carrier melt occurred over typical timescales of $0.14-0.16$ days. This corresponds to indicative magma ascent rates of $0.12-0.29 \mathrm{~m} \mathrm{~s}^{-1}$, assuming closed-system degassing with $\mathrm{H}_{2} \mathrm{O}$ saturation occurring around 1.0-0.4 kbar beneath the vents.

Our petrological and geochemical data are consistent with lateral magma transport from Bárðarbunga to the eruption site in a shallow- to mid-crustal dyke, as has been interpreted using seismic and geodetic data. However, the simplest petrological explanation for the observed geochemical data is one of subvertical magma transport, since our petrological data cannot yet resolve magma transport in the lateral dimension. By combining robust melt inclusion equilibration pressures with diffusion chronometry in zoned magmatic crystals, it may be possible to deduce whether macrocrysts in eruptions of this type were transported laterally through the volcanic system over significant distances within a narrow pressure interval, or were instead entrained from crystal mush horizons close to the vents. Crucially, our results mark a significant step forward in reconciling interpretations of petrological and geophysical datasets for major volcanotectonic episodes, and provides a vital framework for the interpretation of premonitory seismic and geodetic data in volcanically active regions.

Acknowledgements This work was supported by Natural Environment Research Council grants [NE/M021130/1] and [IMF548/1114]. DAN acknowledges support from the Alexander von Humboldt Foundation. We thank Richard Hinton and Cees-Jan de Hoog for their assistance with the SIMS analyses. The samples used in this study were collected by Morten Riishuus, Ármann Höskuldsson, Thorvaldur Thordarson, and the Holuhraun Eruption Team, with the exception of sample EI collected by Evgenia Ilyinskaya. We thank Max Portnyagin and an anonymous reviewer for their insightful comments, which greatly improved the manuscript.

Open Access This article is distributed under the terms of the Creative Commons Attribution 4.0 International License (http://creativecommons.org/licenses/by/4.0/), which permits unrestricted use, distribution, and reproduction in any medium, provided you give appropriate credit to the original author(s) and the source, provide a link to the Creative Commons license, and indicate if changes were made.

\section{Appendix}

An example Python script using our implementation of the OPAM barometer is available from the authors on request.

\section{References}

Ágústsdóttir T, Woods J, Greenfield T, Green RG, White RS, Winder T, Brandsdóttir B, Steinthórsson S, Soosalu H (2016) Strike-slip faulting during the 2014 Bárðarbunga-Holuhraun dike intrusion, central Iceland. Geophys Res Lett 43:1495-1503

Allard P, Burton M, Muré F (2005) Spectroscopic evidence for a lava fountain driven by previously accumulated magmatic gas. Nature 433:407-410

Baker DR (2008) The fidelity of melt inclusions as records of melt composition. Contrib Mineral Petrol 156:377-395

Baker S, Amelung F (2012) Top-down inflation and deflation at the summit of Kilauea Volcano, Hawaii, observed with InSAR. J Geophys Res 117:B12406

Bali E, Hartley ME, Halldórsson SA, Guðfinsson GH, Jakobsson S (2018) Petrology and geochemistry of the 2014-2015 Holuhraun eruption, Iceland: Melt inclusion constraints on degassing history and volatile release. Contrib Mineral Petrol. https://doi.org/10.1007/s00410-017-1434-1 (this issue)

Berndt J, Koepke J, Holtz F (2005) An experimental investigation of the influence of water and oxygen fugacity on differentiation of MORB at $200 \mathrm{MPa}$. J Petrol 46:135-167

Björnsson A, Sæmundsson K, Einarsson P, Tryggvason E, Grönvold K (1977) Current rifting episode in north Iceland. Nature 266:318-323

Botcharnikov RE, Almeev RR, Koepke J, Holtz F (2008) Phase relations and liquid lines of descent in hydrous ferrobasalt-implications for the Skaergaard intrusion and Columbia River flood basalts. J Petrol 49:1678-1727

Breddam K (2002) Kistufell: primitive melt from the Iceland mantle plume. J Petrol 43:345-373

Bucholz CE, Gaetani GA, Behn MD, Shimizu N (2013) Post-entrapment modification of volatiles and oxygen fugacity in olivinehosted melt inclusions. Earth Planet Sci Lett 374:145-155

Burnham CW (1979) The importance of volatile constitutents. In: Yoder HJ (ed) Evolution of the igneous rocks: fiftieth anniversary perspectives. Princeton University Press, pp 439-482

Danyushevsky LV (2001) The effect of small amounts of $\mathrm{H}_{2} \mathrm{O}$ on crystallisation of mid-ocean ridge and Backarc basin magmas. J Volcanol Geotherm Res 110:265-280

Danyushevsky LV, Plechov P (2011) Petrolog3: Integrated software for modeling crystallization processes. Geochem Geophys Geosyst $12: 7$

Danyushevsky LV, Della-Pasqua FN, Sokolov S (2000) Re-equilibration of melt inclusions trapped by magnesian olivine phenocrysts from subduction-related magmas: petrological implications. Contrib Miner Petrol 138:68-83

Danyushevsky LV, Perfit MR, Eggins SM, Falloon TJ (2003) Crustal origin for coupled 'ultra-depleted' and 'plagioclase' signatures in MORB olivine-hosted melt inclusions: evidence from the Siqueiros Transform Fault, East Paific Rise. Contrib Mineral Petrol 144:619-637

Demouchy S, Mackwell S (2006) Mechanisms of hydrogen incorporation and diffusion in iron-bearing olivine. Phys Chem Miner 33:347-355

Dziak RP, Fox CG, Schreiner AE (1995) The June-July 1993 seismoacoustic event at CoAxial segment, Juan de Fuca Ridge: evidence for a lateral dike injection. Geophys Res Lett 22:135-138

Ebinger C, Ayele A, Keir D, Rowland J, Yirgu G, Wright T, Belachew M, Hamling I (2010) Length and timescales of rift faulting and magma intrusion: the Afar rifting cycle from 2005 to present. Ann Rev Earth Planet Sci 38:439-466

Edmonds M (2015) Partitioning of light lithophile elements during basaltic eruptions on Earth and application to Martian shergottites. Earth Planet Sci Lett 411:142-150 
Einarsson P, Brandsdóttir B (1979) Seismological evidence for lateral magma intrusion during the July 1978 deflation of the Krafla volcano in NE-Iceland. Nordic Volcanol Inst 79(9):1-14

Escartín J, Soule SA, Cannat M, Fornari DJ, Düşünür D, Garcia R (2014) Lucky Strike seamount: implications for the emplacement and rifting of segment-centered volcanoes at slow spreading mid-ocean ridges. Geochem Geophys Geosyst 15:4157-4179

Feig ST, Koepke J, Snow JE (2006) Effect of water on tholeiitic basalt phase equilibria: an experimental study under oxidizing conditions. Contrib Miner Petrol 152:611-638

Feig ST, Koepke J, Snow JE (2010) Effect of oxygen fugacity and water on phase equilibria of a hydrous tholeiitic basalt. Contrib Miner Petrol 160:551-568

Ferguson DJ, Gonnerman HM, Ruprecht P, Plank T, Hauri EH, Houghton BF, Swanson DA (2016) Magma decompression rates during explosive eruptions of Kīlauea volcano, Hawaii, recorded by melt embayments. Bull Volcanol 78:71

Fialko YA, Rubin AM (1998) Thermodynamics of lateral dike propagation: implications for crustal accretion at slow spreading midocean ridges. J Geophys Res 103:2501-2514

Fisk MR, Schilling J-G, Sigurdsson H (1980) An experimental investivation of Iceland and Reykjanes Ridge tholeiites: 1. Phase Relations. Contrib Miner Petrol 74:361-374

Gaetani GA, Watson EB (2002) Modeling the major-element evolution of olivine-hosted melt inclusions. Chem Geol 183:25-41

Gaetani GA, O'Leary JA, Shimizu N, Bucholz CE, Newville M (2012) Rapid reequilibration of $\mathrm{H}_{2} \mathrm{O}$ and oxygen fugacity in olivine-hosted melt inclusions. Geology 40:915-918

Gauthier P-J, Sigmarsson O, Gouhier M, Haddadi B, Moune S (2016) Elevated gas flux and trace meltal degassing from the 2014-2015 fissure eruption at the Bárðarbunga volcanic system, Iceland. J Geophys Res 121:1610-1630

Giletti BJ, Shanahan TM (1997) Alkali diffusion in plagioclase feldspar. Chem Geol 139:3-20

Gíslason SR, Stefánsdóttir G, Pfeffer MA, Barsotti S, Jóhannsson Th, Galeczka I, Bali E, Sigmarsson O, Stefánsson A, Keller NS, Sigurdsson Á, Bergsson B, Galle B, Jacobo VC, Arenallo S, Aiuppa A, Jónasdóttir EB, Eiríksdóttir ES, Jakobsson S, Guðfinsson GH, Halldórsson SA, Gunnarsson H, Haddadi B, Jónsdóttir I, Thordarson Th, Riishuus M, Högnadóttir Th, Dürig T, Pedersen GBM, Höskuldsson Ám Gudmundsson MT (2015) Environmental pressure from the 2014-14 eruption of Bárðarbunga volcano, Iceland. Geochem Persp Lett 1:84-93

Grove TL, Kinzler RJ, Bryan WB (1993) Fractionation of mid-ocean ridge basalt (MORB). Geophys Monogr 71:281-310

Gudmundsson A (1995) Infrastructure and mechanics of volcanic systems in Iceland. J Volcanol Geotherm Res 64:1-22

Gudmundsson A, Lecoeur N, Mohajeri N, Thordarson T (2014) Dike emplacement at Bardarbunga, Iceland, induces unusual stress changes, caldera deformation, and earthquakes. Bull Volcanol 76:869

Gudmundsson MT, Jónsdóttir K, Hooper A, Holohan EP, Halldórsson SA, Ófeifsson BG, Cesca S, Vogfjörd KS, Sigmundsson F, Högnadóttir, Einarsson P, Sigmarsson O, Jarosch AH, Jónasson K, Magnússon E, Hreinsdóttir S, Bagnardi M, Parks MM, Hjörleifsdóttir V, Pálsson F, Walter TR, Schöpfer MPJ, Heimann S, Reynolds HI, Sumont S, Bali E, Gudfinsson GH, Dahm T, Roberts MJ, Hensch M, Belart JMC, Spaans K, Jakobsson S, Gudmundsson GB, Fridriksdóttir HM, Drouin V, Dürig T, Aðalgeirsdóttir G, Riishuus MS, Pedersen GBM, van Boeckel T, Oddsson B, Pfeffer MA, Barsotti S, Bergsson B, Donovan A, Burton MR, Aiuppa A (2016) Gradual caldera collapse at Bárdarbinga volcano, Iceland, regulated by lateral magma outflow. Science 353:aaf8988. https://doi.org/10.1126/science.aaf8988
Gurenko AA, Sobolev AV (2006) Crust-primitive magma interaction beneath neovolcanic rift zone of Iceland recorded in gabbro xenoliths from Midfell, SW Iceland. Contrib Mineral Petrol 151:495-520

Halldorsson SA, Oskarsson N, Gronvold K, Sigurdsson G, Sverrisdottir G, Steinthorsson S (2008) Isotopic heterogeneity of the Thjorsa lava-implications for mantle sources and crustal processes within the Eastern Rift Zone, Iceland. Chem Geol 255:305-316

Hamada M, Kawamoo T, Takahashi E, Fujii T (2011) Polybaric degassing of island arc low-K tholeiitic basalt magma recorded by $\mathrm{OH}$ concentrations in Ca-rich plagioclase. Earth Planet Sci Lett 308:259-266

Hansen H, Grönvold K (2000) Plagioclase ultraphyric basalts in Iceland: the mush of the rift. J Volcanol Geotherm Res 98:1-32

Hartley ME, Thordarson T (2012) Formation of Öskjuvatn caldera at Askja, North Iceland: mechanism of caldera collapse and implications for the lateral flow hypothesis. J Volcanol Geotherm Res 227-228:85-101

Hartley ME, Thordarson T (2013) The 1874-76 volcano-tectonic episode at Askja, North Iceland: lateral flow revisited. Geochem Geophys Geosyst 14:2286-2309

Hartley ME, Maclennan J, Edmonds M, Thordarson T (2014) Reconstructing the deep $\mathrm{CO}_{2}$ degassing behaviour of large basaltic fissure eruptions. Earth Planet Sci Lett 393:120-131

Hartley ME, Neave DA, Maclennan J, Edmonds M, Thordarson T (2015) Diffusive over-hydration of olivine-hosted melt inclusions. Earth Planet Sci Lett 425:168-178

Hartley ME, Bali E, Halldórsson SA, Maclennan J, Neave DA, Peate DW (2017) Holuhraun 2014-2015: geochemical constraints on magma storage and transport during a major volcano-tectonic episode. Joint Assembly TSG-VMSG-BGA, Liverpool, 108

Hudson TS, White RS, Brisbourne A, Greenfield T, Ágústsdóttir T, Green RG (2017) Deep crustal melt plumbing under Bárðarbunga volcano, Iceland. Geophys Res Lett 44:8785-8794. https://doi. org/10.1002/2017GL074749

Husen A, Almeev RR, Holtz F (2016) The effect of $\mathrm{H}_{2} \mathrm{O}$ and pressure on multiple saturation and liquid lines of descent in basalt from the Shatsky Rise. J Petrol 57:309-344

Ilyinskaya E, Schmidt A, Mather TA, Pope FD, Witham C, Baxter P, Jóhannssom T, Pfeffer M, Barsotti S, Singh A, Sanderson P, Bergsson B, McCormick Kilbride B, Donovan A, Peters N, Oppenheimer C, Edmonds M (2017) Understanding the environmental impacts of large fissure eruptions: aerosol and gas emissions from the 2014-2015 Holuhraun eruption (Iceland). Earth Planet Sci Lett 472:309-322

Jeir D, Hamling IJ, Ayele A, Calais E, Ebinger C, Wright TJ, Jacques E, Mohamed K, Hammond JOS, Belachew M, Baker E, Rowland JV, Lewi E, Bennati L (2009) Evidence for focused magmatic accretion at segment centers from lateral dike injections captured beneath the Red Sea rift in Afar. Geology 37:59-62

Jenner FE, O'Neill HSC (2012) Analysis of 60 elements in 616 ocean floor basaltic glasses. Geochem Geophys Geosyst 13:Q02005

Johnson EA, Rossman GR (2013) The diffusion behavior of hydrogen in plagioclase feldspar at $800-1000{ }^{\circ} \mathrm{C}$ : implications for reequilibration of hydroxyl in volcanic phenocrysts. Am Mineral 98:1779-1787

Kelley DF, Barton M (2008) Pressures of crystallisation of Icelandic magmas. J Petrol 49:465-492

Langmuir CH, Klein EM, Plank T (1992) Petrological systematics of mid-ocean ridge basalts: constraints on melt generation beneath ocean ridges. In: Morgan JP, Blackman DK, Sinton JM (eds) Mantle flow and melt generation at mid-ocean ridges, Geophys Monogr 71:183-280

Le Voyer M, Asimow PD, Mosenfelder JL, Guan Y, Wallace PJ, Schiano P, Stolper EM, Eiler JM (2014) Zonation of $\mathrm{H}_{2} \mathrm{O}$ and F concentrations around melt inclusions in olivines. J Petrol 4:685-707 
Lloyd AS, Ruprecht P, Hauri EH, Rose W, Gonnerman HM, Plank T (2014) NanoSIMS results from olivine-hosted melt embayments: magma ascent rate during explosive basaltic eruptions. J Volcanol Geotherm Res 283:1-18

Macdonald R, Sparks RSJ, Sigurdsson H, Mattey DP, McGarvie D, Smith RL (1987) The 1875 eruption of Askja volcano, Iceland: combined fractional crystallization and selective contamination in the generation of rhyolitic magma. Mineral Mag 51:183-202

Maclennan J (2008) Concurrent mixing and cooling of melts under Iceland. J Petrol 49:1931-1953

Maclennan J, McKenzie D, Grönvold K, Slater L (2001) Crustal accretion under northern Iceland. Earth Planet Sci Lett 191:295-310

Maclennan J, McKenzie D, Hilton F, Grönvold K, Shimizu N (2003) Geochemical variability in a single flow from northern Iceland. $\mathrm{J}$ Geophys Res 108(B1):2007

Mather TA (2015) Volcanoes and the environment: lessons for understanding Earth's past and future from studies of present-day volcanic emissions. J Volcanol Geotherm Res 304:160-179

Michael PJ (1995) Evidence from trace elements and $\mathrm{H}_{2} \mathrm{O}$ for regionally distinctive sources of depleted MORB: Implications for evolution of the depleted mantle. Earth Planet Sci Lett 131:301-320

Michael PJ, Cornell WC (1998) Influence of spreading rate and magma supply on crystallization and assimilation beneath mid-ocean ridges: evidence from chlorine and major element chemistry of mid-ocean ridge basalts. J Geophys Res 103(B8):18325-18356

Neave DA, Putirka KD (2017) A new clinopyroxene-liquid barometer, and implications for magma storage pressures under Icelandic rift zones. Am Mineral 102:777-794

Neave DA, Passmore E, Maclennan J, Fitton G, Thordarson T (2013) Crystal-melt relationships and the record of deep mixing and crystallization in the AD 1783 Laki eruption, Iceland. J Petrol 54:1661-1690

Neave DA, Maclennan J, Hartley ME, Edmonds M, Thordarson T (2014) Crystal storage and transfer in basaltic systems: the Skuggafjöll eruption, Iceland. J Petrol 12:2311-2346

Neave DA, Maclennan J, Thordarson T, Hartley ME (2015) The evolution and storage of primitive melts in the Eastern Volcanic Zone of Iceland: the $10 \mathrm{ka}$ Grímsvötn tephra series (i.e. the Saksunarvatn ash). Contrib Miner Petrol 170:21

Neave DA, Hartley ME, Maclennan J, Edmonds M, Thordarson T (2017) Volatile and light lithophile elements in high-anorthite plagioclase-hosted melt inclusions from Iceland. Geochim Cosmochim Acta 205:100-118

Newman S, Lowenstern JB (2002) VolatileCalc: a silicate melt- $\mathrm{H}_{2} \mathrm{O}-$ $\mathrm{CO}_{2}$ solution model written in Visual Basic for excel. Comput Geosci 28:597-604

O'Neill HSC, Jenner FE (2012) The global pattern of trace-element distributions in ocean floor basalts. Nature 491:698-704

Óladóttir BA, Sigmarsson O, Larsen G, Devidal JL (2011) Provenance of basaltic tephra from Vatnajökull subglacial volcanoes, Iceland, as determined by major- and trace-element analyses. Holocene 21:1037-1048

Pedersen GBM, Höskuldsson Á, Dürig T, Thordarson T, Jónsdóttir I, Riishuus MS, Óskarsson BV, Dumont S, Magnusson E, Gudmundsson MT, Sigmundsson F, Drouin VJPB., Gallagher C, Askew R, Gudnason J, Moreland WM, Nikkola P, Reynolds HI, Schmith J, IES eruption team (2017) Lava field evolution and emplacement dynamics of the 2014-2014 basaltic fissure eruption at Holuhraun, Iceland. J Volcanol Geotherm Res 340:155-169

Pichavant M, Di Carlo I, Rotolo SG, Scaillet B, Burgisser A, Le Gall $\mathrm{N}$, Martel C (2013) Generation of $\mathrm{CO}_{2}$-rich melts during basalt magma ascent and degassing. Contrib Mineral Petrol 166:545-561

Portnyagin M, Almeev R, Matveev S, Holtz F (2008) Experimental evidence for rapid water exchange between melt inclusions in olivine and host magma. Earth Planet Sci Lett 272:541-552
Putirka KD (2008) Thermometers and barometers for volcanic systems. Rev Mineral Geochem 69:61-120

Qin Z, Lu F, Anderson AT (1992) Diffusive reequilibration of melt and fluid inclusions. Am Mineral 77:565-576

Reynolds HI, Gudmundsson MT, Högnadóttir T, Magnússon E, Pálsson F (2017) Subglacial volcanic activity above a lateral dyke path during the 2014-2015 Bárðarbunga-Holuhraun rifting episode, Iceland. Bull Volcanol 79:38

Roedder E (1984) Fluid inclusions. Rev Miner 12:1-646

Rudge JF, Maclennan J, Stracke A (2013) The geochemical consequences of mixing melts from a heterogeneous mantle. Geochim Cosmochim Acta 114:1120143

Ryan MP (1988) The mechanics and three-dimensional internal structure of active magmatic systems: Kilauea volcano, Hawaii. J Geophys Res 93(B5):4213-4248

Ryan JG, Langmuir CH (1987) The systematics of lithium abundances in young volcanic rocks. Geochim Cosmochim Acta 51:1727-1741

Sigmundsson F, Hooper A, Hreinsdóttir S, Vogfjörd KS, Ófeigsson BG, Heimisson ER, Dumont S, Parks M, Spaans K, Gudmundsson GB, Drouin V, Árnadóttir T, Jónsdóttir K, Gudmundsson MT, Högnadóttir T, Fridriksdóttir HM, Hensch M, Einarsson P, Magnússon E, Samsonov S, Brandsdóttir B, White RS, Ágústsdóttir T, Greenfield T, Grenn RG, Hjartardóttir ÁR, Pedersen R, Bennett RA, Geirsson H, LaFemina P, Björnsson H, Pálsson F, Sturkell E, Bean CJ, Möllhoff M, Braiden AK, Eibl EPS (2015) Segmented lateral dyke growth in a rifting event at Bárðarbunga volcanic system, Iceland. Nature 517:191-195

Sigurdsson H, Sparks RSJ (1978) Lateral magma flow within rifted Icelandic crust. Nature 274:126-130

Stix J, Kobayashi T (2008) Magma dynamics and collapse mechanisms during four historic caldera-forming events. J Geophys Res 113:B09205

Thordarson T, Self S (1993) The Laki (Skaftár Fires) and Grímsvötn eruptions in 1783-1785. Bull Volcanol 55:233-263

Thordarson T, Self S, Óskarsson N, Hulsebosch T (1996) Sulfur, chlorine and fluorine degassing and atmospheric loading by the 17831784 AD Laki (Skaftár Fires) eruption. Bull Volcanol 58:205-225

Thordarson T, Miller DJ, Larsen G (1998) New data on the age and origin of the Leidólfsfell cone group in south Iceland. Jökull 46:3-15

Thy P, Lesher CE, Nielsen TFD, Brooks CK (2006) Experimental constraints on the Skaergaard liquid line of descent. Lithos 92:154-180

Toplis MJ (2005) The thermodynamics of iron and magnesium partitioning between olivine and liquid: criteria for assessing and predicting equilibrium in natural and experimental systems. Contrib Miner Petrol 149:22-39

Toplis MJ, Carroll MR (1995) An experimental study of the influence of oxygen fugacity on Fe-Ti oxide stability, phase relations, and mineral-melt equilibria in ferro-basaltic systems. J Petrol 36:1137-1170

Vogfjörð KS, Hensch M, Hjörleifsdóttir V, Jónsdóttir K (2015) Highprecision mapping of seismicity in the last decades at Bárðarbunga volcano. EGU Conference Abstracts 17:13430V

Voigt M, Coogan LA, von der Handt A (2017) Experimental investigation of the stability of clinopyroxene in mid-ocean ridge basalts: the role of $\mathrm{Cr}$ and $\mathrm{Ca} / \mathrm{Al}$. Lithos 274-275:240-253

Whitaker ML, Nekvasil H, Lindsley DH, Difrancesco NJ (2007) The role of pressure in producing compositional diversity in intraplate basaltic magmas. J Petrol 48:365-393

Whitaker ML, Nekvasil H, Lindsley DH, McCurry M (2008) Can crystallization of olivine tholeiite give rise to potassic rhyolites? An experimental investigation. Bull Volcanol 70:417-434

Witham F, Blundy J, Kohn SC, Lesne P, Dixon JE, Churakov SV, Botcharnikiv R (2012) SolEx: a model for mixed COHSCl-volatile 
solubilities and exsolved gas compositions in basalt. Comput Geosci 45:87-97

Workman RK, Hart SR (2005) Major and trace element composition of the depleted MORB mantle (DMM). Earth Planet Sci Lett 231:53-72

Wright TJ, Ebinger C, Biggs J, Ayele A, Yirgu G, Keir D, Stork A (2006) Magma-maintained rift segmentation at continental rupture in the 2005 Afar dyking episode. Nature 442:291-294
Yang H-J, Kinzler RJ, Grove TL (1996) Experiments and models of anhydrous, basaltic olivine-plagioclase-augite saturated melts from 0.001 to 10 kbar. Contrib Miner Petrol 124:1-18 